\title{
Jacopo Tintoretto’s Female Concert: The Realm of Venus*
}

\author{
Liana De Girolami Cheney \\ Università di Aldo Moro, Bari, Italy
}

\begin{abstract}
This study aims to visualize Giorgio Vasari's statement in discussing Jacopo Tintoretto's Female Concert of 1576-86, now at the Gemäldegalerie Alte Meister in Dresden (see Figure 1). Two conceits (concetti) are considered in analyzing Tintoretto’s female imagery: (1) a fanciful invention of musica extravaganza; and (2) a Venetian allegory of bellezza. The first part of the essay discusses the provenance of the painting and the second part presents an iconographical interpretation of the imagery. This essay also focuses on the iconography of the painting based on viewing the subject and does not postulate on its iconography based on disappeared paintings or on a speculative decorative cycle on the theme of Hercules. Relying on well-documented research on music in Venice, on Mannerist practices, and on art theories during Tintoretto’s life, some intriguing observations are made about the painting.
\end{abstract}

Keywords: beauty, music, iconography, alchemy, interpretation, mythology, muses, Neoplatonism, Venus

"E vera cosa che la musica ha la sua propria sede in questa città" ("It is true that music has its own official seat in this city [Venice]”)

-Francesco Sansovino

Venetia città nobilissima (Venice, 1581$)^{1}$

\section{Introduction}

In Venice in 1566, Giorgio Vasari (1511-74), a Florentine artist and writer, met the Venetian painter and musician, Jacopo Comin Robusti, known as Tintoretto (1518-94). In his Vite of 1568, Vasari praised Tintoretto's musical and artistic talents in this manner:

Tintoretto, who has delighted in all the arts, and particularly in playing various musical instruments, besides being agreeable in his every action, but in the matter of painting swift, resolute, fantastic, and extravagant, and the most extraordinary brain that the art of painting has ever produced, as may be seen from all his works and from the fantastic compositions of his scenes, executed by him in a fashion of his own and contrary to the use of other painters. Indeed, he

\footnotetext{
${ }^{*}$ Acknowledgements: Versions of this essay were presented at the Session on Music and Art, sponsored by the Association for Textual Scholarship in Art History, at the College Art Association (CAA) in Chicago on 14 February 2014, and at Save Venice of Boston on 30 January 2015. I am grateful for the comments of Professor. Katherine Powers, Professor of Music at Fullerton University, Les Brothers, Professor of Music at The University of Missouri in Saint Louis, Brian Steele, Associate Professor of Art History at Texas Tech University, and Sarah Lippert, Associate Professor of Art History at University of Michigan-Flint.

Liana De Girolami Cheney, Ph.D., is a Visiting Researcher in Art History at the Università di Aldo Moro, in Bari, Italy. lianacheney@earthlink.net.

${ }^{1}$ See Francesco Sansovino (1581), Venetia città nobilissima, p. 380, one of the first printed guides of Venice. See also Viviana Comensoli, "Music, The Book of the Courtier, and Othello's Soldiership", in The Italian World of English Renaissance Drama: Cultural Exchange and Intertextuality, pp. 89-105, for a discussion on music theory in the Italian Renaissance as well as Neoplatonic theory on the superiority of the senses, in particular, the sense of hearing.
} 
has surpassed even the limits of extravagance with the new and fanciful inventions and the strange vagaries of his intellect, working at haphazard and without design, as if to prove that art is but a jest. ${ }^{2}$ (Vasari, 1568, p. 468)

This study aims to visualize Vasari’s statement in discussing Tintoretto’s Female Concert of 1576-86, now at the Gemäldegalerie Alte Meister in Dresden (see Figure 1). Two conceits (concetti) are considered in analyzing Tintoretto’s female imagery: (1) a fanciful invention of musica extravaganza; and (2) a Venetian allegory of bellezza. The first part of the essay discusses the provenance of the painting and the second part presents an iconographical interpretation of the imagery. The first conceit relates to the invention of musica, which is associated with the Muses, Goddesses of Music, Knowledge, and Artistry. There were nine Muses (Clio, Euterpe, Thalia, Melpomene, Terpsichore, Erato, Polyhymnia, Urania, and Calliope) who invented chords and vibrations in musical instruments and developed the art and technique of combining sounds in time and space with various musical instruments. These Muses, guided by Apollo, God of Music, Light and Prophecy, inspired artists, philosophers and poets in their creations, thus ruling over the visual and performing arts. $^{3}$

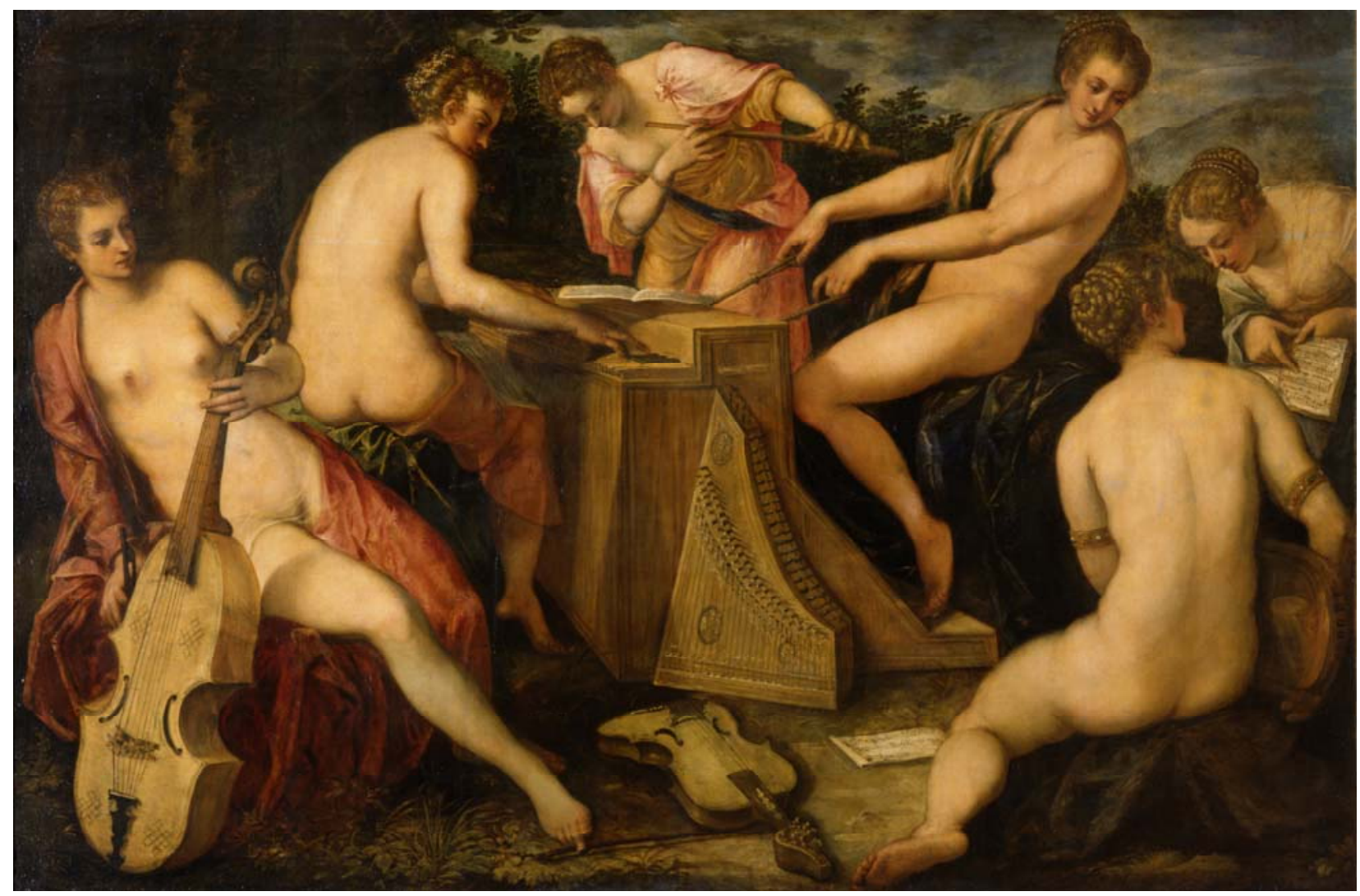

Figure 1. Jacopo Tintoretto, Female Concert, 1576-86. (Gemäldegalerie Alte Meister, Dresden, Germany; Photo credit: Gemäldegalerie Alte Meister, Dresden, Germany; Public Domain, via Wikimedia Commons)

\footnotetext{
2 See Giorgio Vasari (1568), “Vita di Jacopo Tintoretto”, in Giorgio Vasari Vite de’ più eccellenti Pittori, Scultori e Architettori nelle redazioni del 1550 e 1568, Rosanna Bettarini and Paola Barocchi (Ed.), 6 vols. (1963-1989), V, 468, and David Rosand (1986/1997), Painting in Cinquecento Venice: Titian, Veronese, Tintoretto, pp. 159-164.

${ }^{3}$ See Liana De Girolami Cheney (Spring 1994), “Giorgio Vasari’s Pictorial Musing on the Muses: The Chamber of Apollo of the Casa Vasari”, Studies in Iconography, 15, 135-77.
} 
The second conceit, bellezza or venustas (beauty, loveliness, and goodness), originated from Vitruvius's theory of beauty. He based his theory on forms in nature and derived universal laws of proportions applied to geometrical forms such as the square and the circle as well as to proportional human forms. This complicated theory of beauty was much debated in the Renaissance. ${ }^{4}$ The conceit of beauty consisted of two aspects: (1) the physical, which was related to measurement and human proportions; and (2) the metaphysical, which was revealed in the apprehension of the essence of the visual form. ${ }^{5}$

In 1984, Erasmus Weddigen wrote a stimulating article on "Jacopo Tintoretto and Music" in Artibus et Historiae. $^{6}$ The article addresses the complex iconography of musical symbolism in Venetian paintings of the Cinquecento, including the works of Giorgione, Titian, Veronese, and, especially, Tintoretto. Weddigen's analysis also includes themes associated with musical instruments and mythology such as The Contest of Apollo and Marsyas, Apollo and the Muses, Minerva and the Muses, The Contest with the Muses, and The Muses. He further discusses the historical background of Venetian music and musicians in the Cinquecento, focusing on specific love themes, musical compositions, and musical performances.

Four years after the German article by Weddigen, H. Colin Slim wrote two related articles: "A Painting about Music at Dresden by Jacopo Tintoretto", in Exploration in Renaissance Culture, and "Tintoretto's Music-Making Women at Dresden”, in Imago Musicae, in which he incorporates and expands on Weddigen's ideas in English. ${ }^{7}$

\section{History of the Commission}

A historical summary of what it is known about the commission of Tintoretto's Female Concert assists in the analysis of the painting. This painting is also referred to as Music-Making Women, Women Making Music, and Concert with Women Making Music. The painting was part of an art collection of more than 3,000 paintings belonging to the Holy Roman Emperor Rudolph II (1552-1612) at his court in Prague. ${ }^{8}$

In 1648, Tintoretto's biographer Carlo Ridolfi, residing in Venice, described in Vita di Giacoppo Robusti detto il Tintoretto (The Life of Jacob Robusti called il Tintoretto) and in the Meraviglie dell' Arte (The Wonders of Art $)^{9}$ four paintings that Tintoretto completed for Emperor Rudolph II around 1576, including: (1) Jupiter bringing the young Bacchus, born of Semele, to Juno for nursing; (2) Silenus entering Hercules's bedroom thinking that he is making love to Iole; (3) Hercules looking at a mirror ornamented with lascivious women by Iole; and (4) a fourth painting "where in a garden Muses, reduced in number, are making music with

\footnotetext{
${ }^{4}$ See Anthony Grafton, Leon Battista Alberti: Master Builder of the Italian Renaissance, pp. 274-275, for a discussion of Vitruvius' venustas applied to the Renaissance art; Anthony Blunt (1968), Artistic theory in Italy, 1450-1600, pp. 15-18; and André Chastel (1975), Marsile Ficin et L'Art, pp. 107-114, on Alberti’s concept of beauty as related to music and to Renaissance Neoplatonism.

${ }^{5}$ See Chastel (1975), Marsile Ficin et L'Art, pp. 81-85, for the concept of beauty related to Renaissance Neoplatonism.

${ }^{6}$ See Erasmus Weddigen (1984), “Jacopo Tintoretto und die Musik”, Artibus et Historiae, 5 (10), 67-119.

7 See Carlo Ridolfi (2006), Le Meraviglie dell'Arte, 2 Vols., II, p. 226. H. Colin Slim (1987), “A Painting about Music at Dresden by Jacopo Tintoretto", Exploration in Renaissance Culture, 13, 1-18, and “Tintoretto's Music-Making Women at Dresden”, Imago Musicae, 4 (1988), 45-76.

8 See Rotraud Bauer (1976), “Die Kunstkammer Kaiser Rudolfs II. In Prag: Inventar aus den Jahren 1607-1611”, Jahrbuch der Kunsthistorischen Sammlungen in Wien 72, XIV (report from 5 March 1612); Julius Hübner (1856/1862/1868), Verzeichnis der Königlichen Gemälde-Gallerie zu Dresden, 121, no. 267, 150, no. 292, and 127, no. 292, respectively; no editor, Gemäldegalerie Alte Meister Dresden: Katalog der ausgestellten Werke (1982), 318, no. 265; and Heinrich Zimmerman (1905), "Das Inventar der Prager Schartz-und Kunstkammer vom 6. Dezember 1621”, Jahrbuch der kunsthistorischen Sammlungen des allerhöchsten Kaiserhauses, XLII, no. 1036.

${ }_{9}^{9}$ Carlo Ridolfi (1984), Life of Tintoretto, and His Children Domenico and Marietta, 2 Vols., Robert Enggass (Trans.), cited in Rudolfo Pallucchini and Paola Rossi, Jacopo Tintoretto: Le opere sacre e profane (1982), I, pp. 92, 175, no. 204.
} 
various instruments" ("Le Muse che, ridotte in un giardino, formano un concerto di Musica con varii strumenti”). ${ }^{10}$ This description is usually associated with Tintoretto's Female Concert recorded in the collection of the Emperor's inventories of 1621 and 1648. ${ }^{11}$ The other three paintings are lost.

Rudolph II's collection endured a cruel fate during and after the Thirty Year's War that finally ended in 1648. During the war the collection was partially pillaged by the Swedish army. A portion of the collection was moved to the palace of Queen Christina of Sweden (1626-89) in Stockholm, and the rest of the collection was kept in the Prague palace. Queen Christina further disassembled her collection by moving some of those pictures from Stockholm to Rome to form part of a new art gallery at her Roman residence. ${ }^{12}$

Further records show that Tintoretto's Female Concert remained in the collection of the Prague palace until 1744. At that time, the painting was sold to Graf Villio, a Saxon Ambassador to Venice (1733-44), by the Holy Roman Empress Maria Theresa (1717-80) in order to raise money to support her battles against Frederick the Great, King of Prussia (1740-86), during the Seven Year's War (1754-63). In 1749, Tintoretto's painting was finally acquired by The Dresden Gemäldegalerie in Germany, where it is still on display. ${ }^{13}$

\section{Iconographical Interpretation: Musical Sources}

Several scholarly attempts have been made to understand the iconography of Tintoretto's four mythological paintings, which were commissioned by Rudolph II, Holy Roman Emperor, for his chambers in the palace at Prague. However, no clear explanation of the symbolism of these painting has yet been formulated. There are compelling arguments to incorporate the four pictures as part of a decorative cycle on the theme of Hercules based on Lilio Gregorio Giraldi's (1479-1552) Herculis vitae, but these are inconclusive. ${ }^{14}$ The difficulty in these assessments arises with the past and present historical provenance of the paintings, since three of them are not traceable, thus forcing interpretation or misinterpretation that detracts from the signification of the extant painting, Tintoretto's Female Concert.

This essay focuses on the iconography of the painting based on viewing the subject and does not postulate on its iconography based on disappeared paintings or on a speculative decorative cycle on the theme of Hercules. Relying on well-documented research into music in Venice and Mannerist artistic practices during Tintoretto's lifetime, some intriguing observations are made about the painting.

Moreover, there are three important factors in considering Tintoretto's Female Concert. First, Venice had a longstanding tradition of high-quality publishing and printing, including musical texts. In Venice, the printing trade was well established and was a substantial part of Venetian trade with Antwerp, Basel, and Paris. ${ }^{15}$ Second, Venice was a center for musical composers and musicians such as Jacques Archadelt (1507-68),

\footnotetext{
${ }^{10}$ See Ridolfi, Le Meraviglie dell'Arte, II, pp. 226-227, description of the four paintings: "In uno le Muse che, ridotte in un giardino, formano un concerto di musica con varii strumenti. Nell'altro Giove, che reca [leca] all seno di Giunone Bacco fanciullo, nata di Semele. Il terzo era di Sileno entrato al bujo nel letto di Ercole, credendosi goder Jole. Ercole medesimo nel quarto, che si mira in uno specchio adorno di lascivie feminnile dalla medesima Jole.”

${ }_{11}$ See H. Colin Slim (1987), “A Painting about Music at Dresden by Jacopo Tintoretto”, Exploration in Renaissance Culture, 13, 1.

12 See Bela Dudik (1867), "Die Rudolfinische Kunst-und Rarirätenkammer in Prag”, Mitteilungen der K. K. Central Commission zur Erforschung und Erhaltung der Baudenkmale 12, XXXIX, no. 291.

${ }^{13}$ Folio 34 recto of $1747-50$ of the museum registry lists that Tintoretto's Female Concert "is acquired from the Imperial Collection of Rudolph II of Prague. In 1742, King August III sold to the Gallery-Inspector Riedel and in 1749 bought by the Gallery-Inspector Guarienti”; correspondence with Dr. Judith Claus, Curatorial Staff, Gemäldegalerie Alte Meister, Staatliche Kunstsammlungen Dresden, Germany, 17 February 2014. I am grateful for the assistance and suggestions of Dr. Judith Claus.

${ }_{14}$ See Slim, “A Painting about Music at Dresden by Jacopo Tintoretto”, p. 6.

15 See Iain Fenlon (1994), Music, Print and Culture in Early Sixteenth-Century Italy, The Panizzi Lectures of 1994, pp. 56, 59.
} 
Domenico Bianchini (1510-76), Anton Francesco Doni (1513-74), Andrea Gabrielli (1532-85), Gioseffo Zarlino (1517-90), and Giulio Zacchino (1555-84). ${ }^{16}$ And third, the early sixteenth-century female ensemble or concerto delle donne was developed and organized in the courts of Italy. ${ }^{17}$

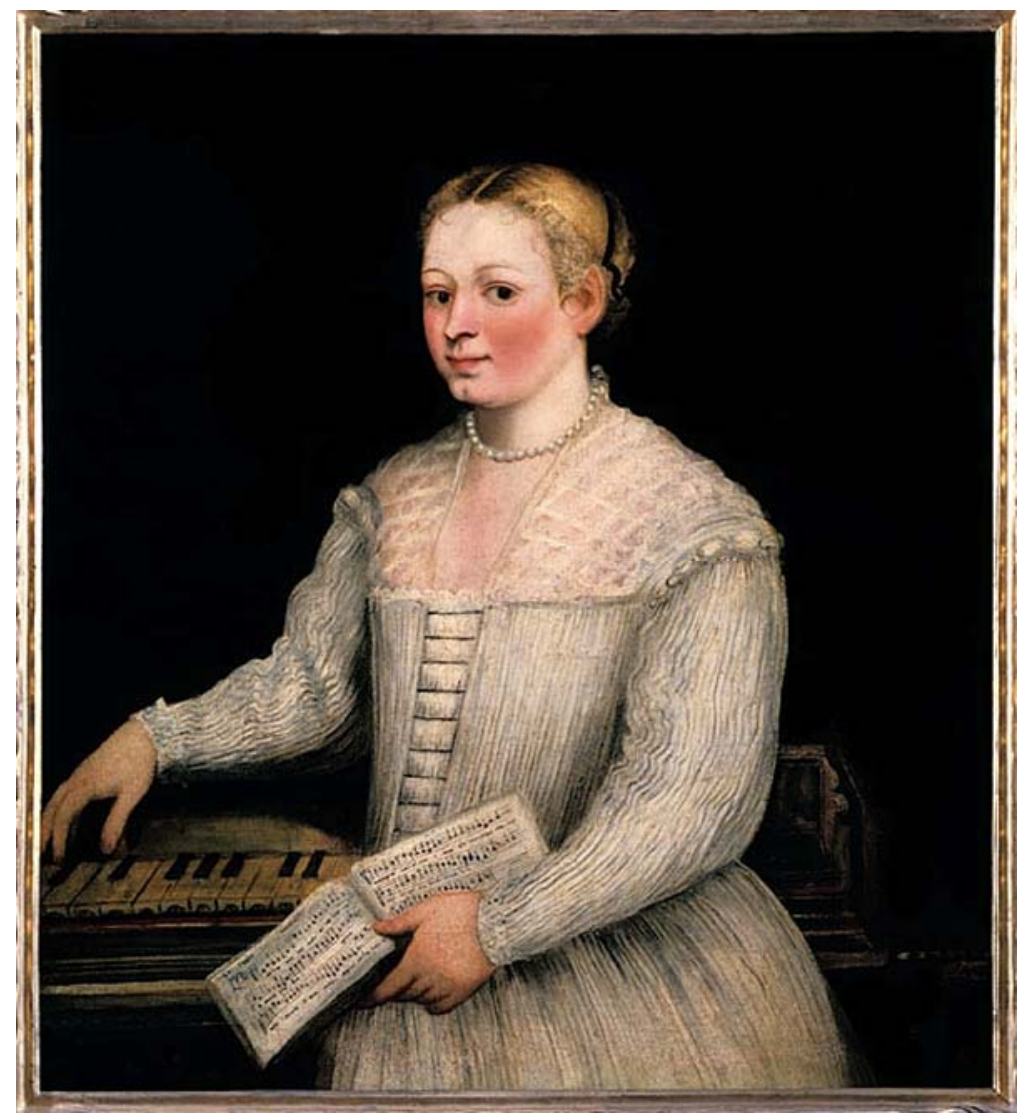

Figure 2. Marietta Robusti, La Tintoretta, Self-Portrait, 1585. (Corridoio Vasariano, Galleria degli Uffizi, Florence; Photo Credit: Scala/Art Resource, NY [ART 107870])

Vasari was not the only writer who acknowledged Tintoretto's musical talents and love for music. In 1548, Andrea Calmo (1510-70), a satirical poet, epistolary writer, and dramatic actor in the Commedia dell'Arte, praised his friend Tintoretto in a letter for "playing, laughing and singing, so as not to damage the brain". ${ }^{18}$ And in 1648, in Vita di Giacoppo Robusti detto il Tintoretto, the Venetian biographer Ridolfi noted that Tintoretto in his youth enjoyed playing the lute and other musical instruments. ${ }^{19}$ Tintoretto delighted in cultivating and socializing with Venetian musicians such as Domenico Bianchini (Il Rosetto, ca.1510-76), Gioseffo Zarlino (1517-90), and Giulio Zacchino (1555-84). The latter instructed his daughter, Marietta (1555-90), to play the spinet or virginal and to sing as depicted in her Self-Portrait of 1585 at the Galleria degli Uffizi in Florence (see Figure 2). ${ }^{20}$ Musical attributes are visible in the painting; for example, a spinet and a note score that records a madrigal of a well-known love song, "Madonna per voi ardo..." ("My lady, I burn

\footnotetext{
${ }^{16}$ Fenlon, Music, Print and Culture, pp. 71, 80.

17 See Karin Pendle (1991) (Ed.), Women and Music: A History, pp. 37-34, and Jane L. Baldauf-Berdes (1996), Women Musicians of Venice: Musical Foundations, 1525-1855, pp. 39-42.

${ }^{18}$ Citation in Weddigen, “Jacopo Tintoretto und die Music," Artibus et Historiae, 10, 68.

19 Weddigen (1984), “Jacopo Tintoretto und die Music”, p. 68.

20 See Liana De Girolami Cheney, et al. (2000/2011), Self-Portraits by Women Painters, 64.
} 
with love for you and you do not believe it”) by Philippe Verdelot (1480-1532), known as the father of the Italian madrigal.

In their studies on Tintoretto's Female Concert, Weddigen and Slim identified several musical scores depicted in the painting, in particular, the two composers of the sources. These two identifications derive from Tintoretto's depiction of two musical scores, whose first legible lines can be decoded. One derives from an anonymous Neapolitan poem, Dolc'amorose e leggiadrette ninfe ("Sweet loving and graceful Nymphs") ${ }^{21}$ and the other from the madrigal by Andrea Gabrieli (1533-85), "Quanto lieta ver noi sorge l'Aurora” ("How delightful is to see the rising of Aurora"). ${ }^{22}$

The Neapolitan poem, Dolc'amorose e leggiadrette ninfe, became musically interpreted in Giovan Leonardo Primavera's canzone napoletane (secular songs) in 1565, 1566, and $1570 .{ }^{23}$ As a composer Primavera (1540-85) performed in Venice where Tintoretto probably visually appropriated his musical conceit in his painting. Gabrielli's Aurora was published in a musical book, Il primo libro di madrigal a cinque voci ("First book of madrigals for five voices") in Venice by Antonio Gardano in 1566 and 1572. The score included the first lines of the madrigal: "Quanto lieta ver noi sorge l'Aurora" ("How delightful is to see the rising of Aurora”).

Another musical source for the Venetian painting is from the music of Zarlino. He was appointed maestro di cappella at the church of Saint Mark in 1565, and invited Andrea Gabrielli to be his second organist in $1566 .{ }^{24}$ Zarlino's musical theory of the six sonorous numbers, scenario, was likely an influence in Tintoretto's selection of six performers in the Female Concert.

In addition, Weddigen and Slim identified the musical instruments employed by the muses in Tintoretto's Female Concert. There are four string instruments in the foreground of the painting: from left to right, a bowed viola da gamba, a lira da braccio, a plucked psaltery and a cittern (probably a cithara), complemented by wind instruments including a cornet (probably a type of cornet to or recorder) and a regal. A singer accompanies these musicians.

\section{Iconographical Interpretation: Artistic Sources}

The background of Tintoretto's Female Concert depicts a radiant atmosphere in the sky, revealing the painting's mood. Tintoretto portrayed a sunrise of spring under the governance of Aurora, the Goddess of Dawn and Sunrise. The natural phenomenon of Aurora's lights displays the shifting of colors from red to yellow-green, as in the formation of the aurora borealis, which created a symphony of light. Perhaps this is one reason why Tintoretto's palette is predominantly red and green in the painting, alluding to a painterly aurora borealis. This astral occurrence was known in ancient times and was referred to as "blazing sky" or "flaming sky" by Hesiod in his Theogony. ${ }^{25}$ This Greek text was available in the Renaissance through the printing of Aldus Manutius in 1495 in Venice. The cosmic phenomenon known as “Aurora Borealis” or "Northern Dawn”,

\footnotetext{
${ }^{21}$ See Slim, “A Painting about Music at Dresden by Jacopo Tintoretto”, 4, notes 15 and 16.

22 See Slim, “Tintoretto’s Music-Making Women”, p. 53.

23 See Slim, “A Painting about Music at Dresden by Jacopo Tintoretto”, 4, notes 15 and 16.

${ }^{24}$ See Slim, “Tintoretto’s Music-Making Women”, p. 53.

${ }^{25}$ See Hesiod (1832), Theogony, trans. and annotated by C. A. Elton, Esq., line 378ff, on Boreas and Eos (Dawn or Aurora); line 630ff, on "brazen sky"; and lines 1080-85, the four winds—north, south, east and west. See also George Siscoe (1986), "An Historical Footnote on the Origin of "Aurora Borealis'”, History of Geophysics, 2, 11-14, and see from http://www.nasa.gov/mission_pages/themis/auroras/aurora_history.html\#.VBNEAEs1fE.
} 
however, refers to a term for a morning blazing sky coined by Galileo Galilei in $1619 .^{26}$ He associated the marvel of a flaming sky with Aurora, the Roman Morning Goddess, and Borealis the northern light and Wind God, Boreas.

Tintoretto's painting is staged in a pastoral landscape, a spring with a luminous sunrise, a dawn or aurora. The background of the painting is divided into two parts: on the left of the painting there is a thickly wooded forest, where tree trunks are in the shape of male figures; on the right there is an open sky with an aurora borealis. The composition of the painting is horizontally divided into three parts: on the left, a muse holds a viola da gamba and touches the bow of a lira da braccio with one of her toes; in the center, three muses are encircling a regal while reading and playing music; and at the right a muse holds a cithara while attending to the musical instructions of her sister muse. Tintoretto invented a musical triptych. The placement of the musical instruments, some held by the muses and others resting on the grass, introduces the viewer to the concert, from the viola da gamba on the left, to the regal, cornetto, psaltery, and lira da braccio in the center, and the cithara on the right. Furthermore, he creates a contrapuntal arrangement with the poses of the figures; some turn toward the picture plane, while others move away from the frontal plane of the painting. The muses' physiognomy is similar. What is different is their attire or lack of it and the musical instrument or musical score that each holds. Four of these muses are nude, while two females are clothed in antique garments. Their blonde tresses are decorated with pearls or flowers and coiled in a chignon or donut-style hairdo.

Forming a semicircle inside the pictorial composition, there are only six females or muses engaged in a musical performance. Some of the instruments are held by the muses (the viola da gamba, the cornet and the cithara), while others are displayed on the ground (the lira da braccio and psaltery). Two nude muses play the regal instrument. Four different musical scores are displayed throughout the composition. The score on the ground, next to the musical instruments, is temporarily ignored, while one rests on the lap of one of the regal players, and the other two scores are being consulted by the clothed muses.

One muse, standing next to the regal on which the musical score is resting, holds a recorder and attentively reads the musical score. To her far left, the other clothed muse is raising the musical score and pointing out a passage to the nude muse who embraces a cithara. The consultation between these two muses is intriguing. The clothed muse holding the musical score is instructing the nude muse embracing a cithara how to accompany with her instrument, perhaps alluding to Il primo libro di tabolatura di cithara di ricercati madrigali ("First tabulator book for cithara of well-known madrigals"), the recently published book on interpreting Neapolitan love songs and salterelli with a cithara, written by Paolo Virchi from Brescia (1555-1610) and printed in Venice in 1572 by Girolamo Scotto (1505-72).

The cithara that the nude female holds is an ancient musical instrument. The word derives from the Latin name for a musical strung instrument played with a quill or plectrum, chitara, or from the Greek musical instrument, kithara, meaning the sound of sea snails found on the island of Kythera or Cythera. Because Tintoretto's nude muse holds a cithara, she may be identified in relation to the traditional portrayal of musical muses. She may personify Terpsichore, the Muse of Dance, who traditionally dances while playing the cithara, as seen in Terpsichore, Muse of Dance with Cithara, 1st century BCE, a Greek relief in the Archeological

\footnotetext{
${ }^{26}$ Some scholars claim that a French scientist, Pierre Gassendi, coined the term in 1621. See S. I. Akasofu (1979/1994), “Aurora Borealis”, Alaska Geographic Society, 6(2), 124-6.
} 
Museum of Istanbul. Or she could also be Erato, the Muse of Lyric Poetry, who chants her lyrics while playing the cithara, as seen in Erato, Muse of Lyric Poetry with Cithara, 1st century CE, now at the Vatican Museum (see Figure 3).

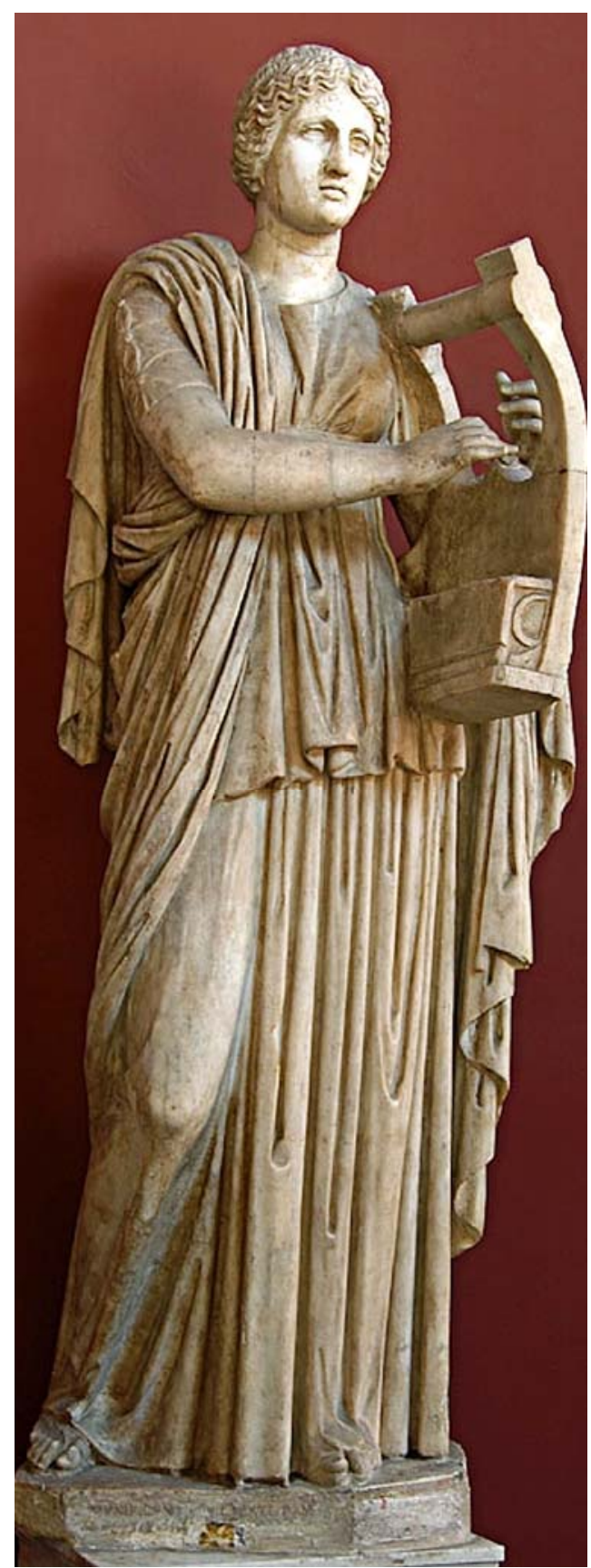

Figure 3. Erato, Muse of Lyric Poetry with Cithara, 2nd century CE. (Pius-Clementine Museum, Room of the Muses, 23, Vatican Museums, Rome; Photo credit: author. Courtesy of the Vatican Museums [Inv. No. 317], Rome)

Listening attentively to her interlocutor, the nude muse-whose back is facing the viewer-is different from her sister nude muses: their nude bodies are gently adorned with a minimal wrap, while she wears none. In addition to embracing the cithara and holding a plectrum, this nude muse sits in a classical pose alluding to a 
popular Hellenistic copy of Amor and Psyche made in marble and in bronze in the Cinquecento. This ancient relief was referred to as the Bed of Polycleitus. In the sixteenth century there were several marble fragments of the Bed of Polycleitus (see Figure 4), which was a Roman copy of a Hellenistic relief of Amor and Psyche (now in a private collection). Cardinal Antoine Perrenut de Granville (1517-86), an avid collector of art who was employed as minister by the Spanish Habsburgs and connected with the court of Rudolph II in Prague, also owned a copy of this relief. ${ }^{27}$ Titian, a Venetian painter and Tintoretto's mentor, appropriated the ancient imagery of the Bed of Polycleitus for his painting Venus and Adonis of 1553 (see Figure 5), a commission received from Philip II, King of Spain, now at the Prado Museum. Titian and Tintoretto probably were familiar with a bronze copy of the Bed of Polycleitus owned by Pietro Bembo (1470-1547), the Venetian poet and madrigal theorist who inspired many of their mythological paintings. ${ }^{28}$

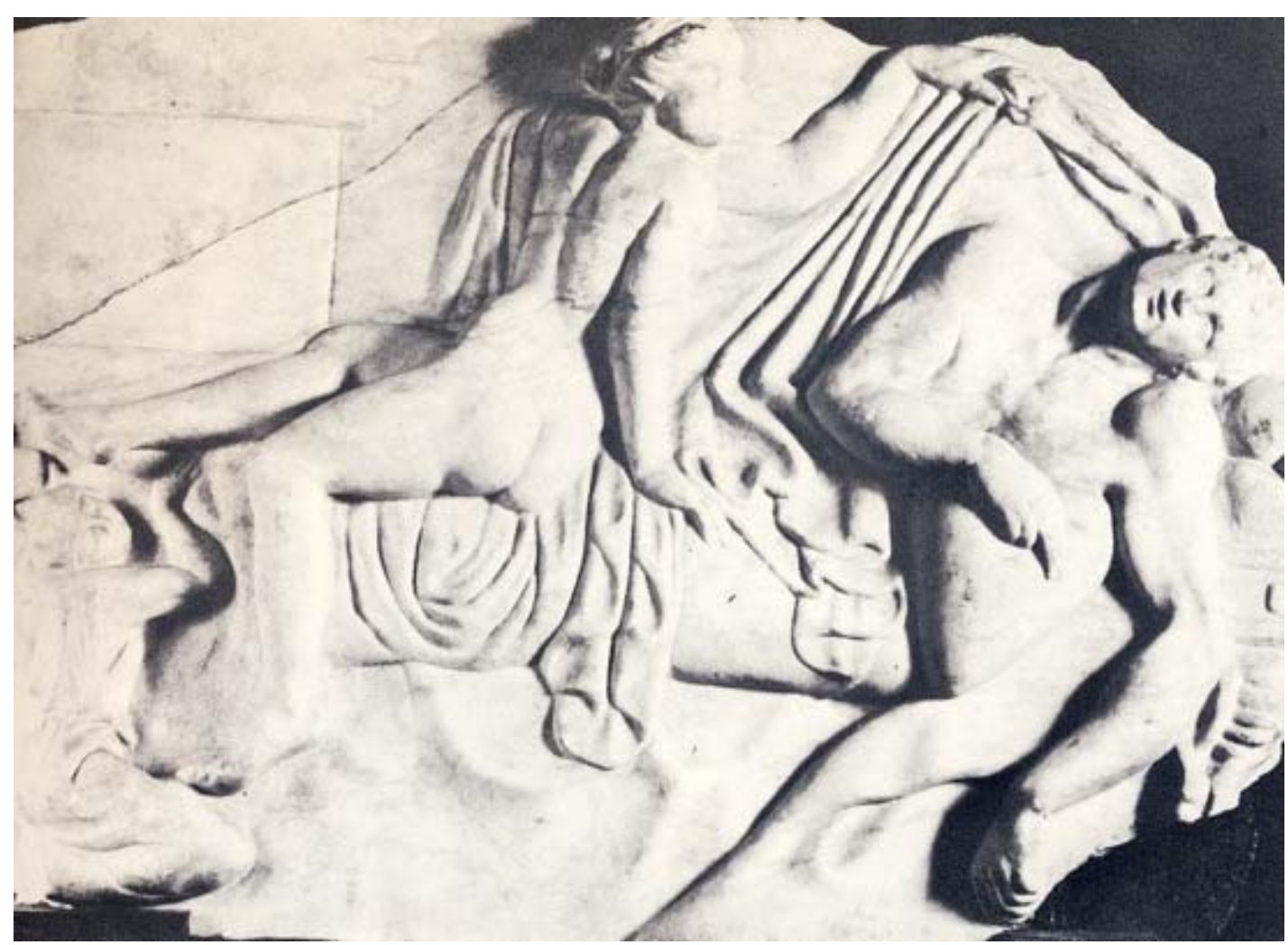

Figure 4. Bed of Polycleitus, sixteenth-century copy of Amor and Psyche. (Hellenistic relief. Private collection. Photo credit: author)

\footnotetext{
27 See Phyllis Pray Bober and Ruth Rubenstein, Renaissance Artists and Antique Sculpture, p. 127.

${ }^{28}$ Bober and Rubenstein (1986), Renaissance Artists, p. 127. Also, an exhibition in Padua, Petro Bembo and the invention of the Renaissance, at the Palazzo Monte di Pietà, Fall 2013, reunited works from Bembo's collection of ancient art, which was dismantled after his death.
} 


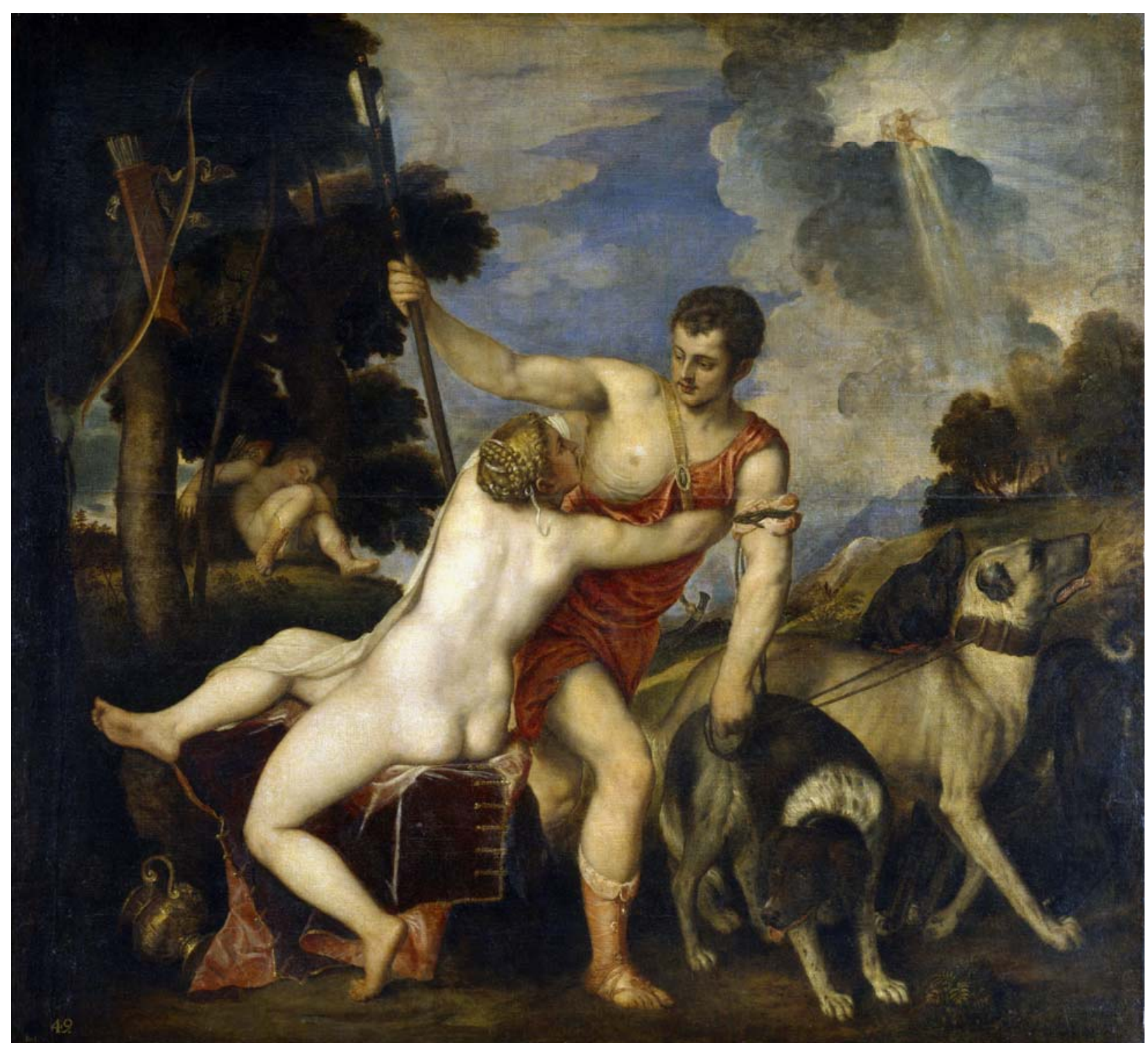

Figure 5. Titian, Venus and Adonis, 1553. (Museo Nacional del Prado, Madrid, Spain; Photo credit: Art Resource, NY [ART 466119])

Tintoretto's nude muse also wears golden bracelets encrusted with gemstones such as emeralds, pearls, and rubies. Since antiquity, upper-arm bracelets have been associated with Venus, as seen in Crouching Venus (1st century BCE, now at the Vatican Museum) (see Figure 6), who wears an upper-arm bracelet on both arms. ${ }^{29}$ Pearls, in particular, are attributes of Venus, because they are formed in the sea within the soft tissue of a living mollusk, reminiscent of the birth of Venus or Aphrodite (a Greek word meaning born from the foam of the sea), who was born from the foam of Uranus' testicles discarded in the sea, as seen in the lekythos in the form of Aphrodite, Greek mid-fourth century BCE, now at the Boston Museum of Fine Arts. ${ }^{30}$ In addition, pearls, unlike any other gemstones, are naturally formed in a shell, created with their own perfection and beauty;

${ }^{29}$ In La Fornarina of 1518 at the Galleria Nazionale d'Arte Antica in Rome, Raphael appropriates this conceit and decorates the arm of his muse with a bracelet holding his name, thus signing his painting as well as acknowledging his love for La Fornarina. ${ }^{30}$ See Hesiod (1988), Theogony (M. L. West, Trans. \& Ed.), lines 176-188, and Guy de Tervarent (1997), Attributs et Symboles dans L'Art Profane, p. 145, on the symbols of the shell and Venus. 
hence the pearl's association with beauty. ${ }^{31}$ Like the pearl, Aphrodite is associated with formation in the sea according to ancient legend. ${ }^{32}$ Aphrodite is carried ashore in a seashell, as seen in her traditional depiction since antiquity of navigating on a seashell (see Figure 7); e.g., the Pompeian fresco painting after Apelles' Aphrodite Anadyomene, before $79 \mathrm{CE}$, now at the Archeological Museum in Naples, or the well known Renaissance painting of Botticelli's Birth of Venus of 1485, now at the Galleria degli Uffizi in Florence. As Aphrodite rises from the sea, legend recounts, droplets of water transformed into pearls allude to the beauty of the deity. ${ }^{33}$ In antiquity, pearls were coveted as a symbol of wealth and power, and men gifted their lovers with pearls; hence the pearl's association with love. ${ }^{34}$

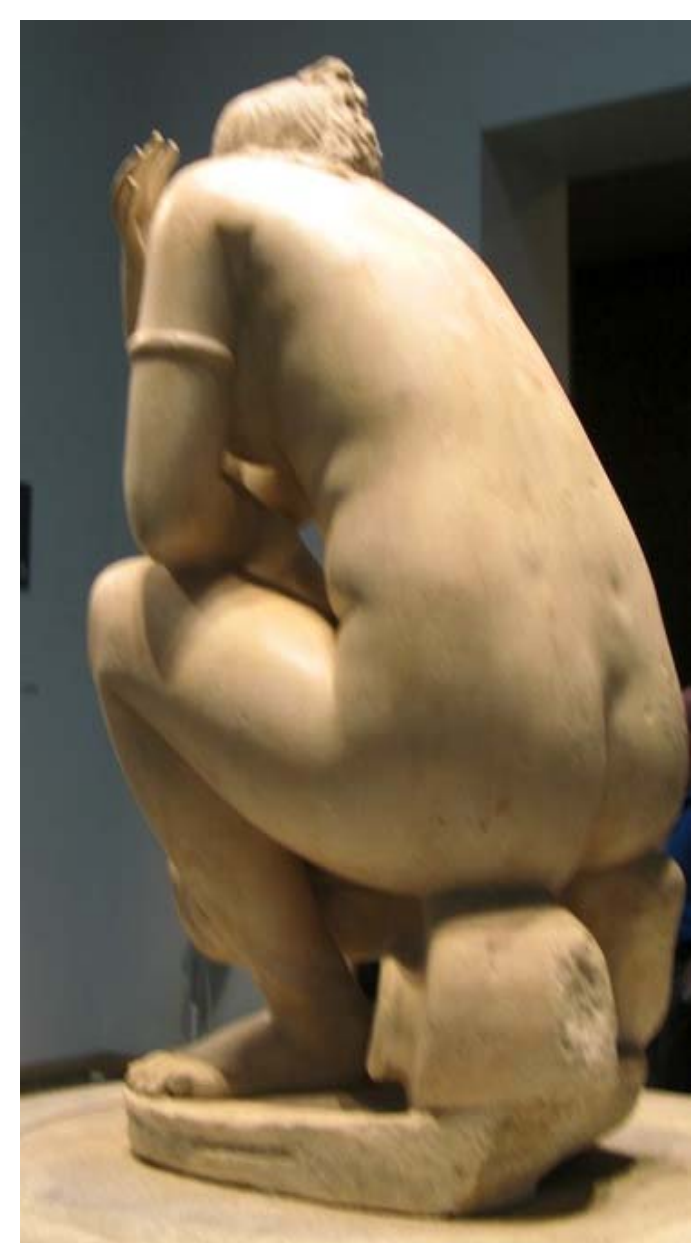

Figure 6. Crouching Venus, Lely Venus, 1st century BCE, marble. (Sir Peter Lely, Royal Collection, on loan to the British Museum, London; Photo credit: author. Courtesy of the British Museum, London)

\footnotetext{
${ }^{31}$ See Jean Chevalier and Alain Gheerbrant (1994), A Dictionary of Symbols, pp. 743-744, and Hans Biedermann (1994), Dictionary of Symbolism: Cultural Icons and the Meanings Behind Them, p. 259.

32 See Hesiod, Theogony, lines 176-188.

33 See Chevalier and Gheerbrant, A Dictionary of Symbols, p. 744.

34 See Chevalier and Gheerbrant, A Dictionary of Symbols, p. 743.
} 


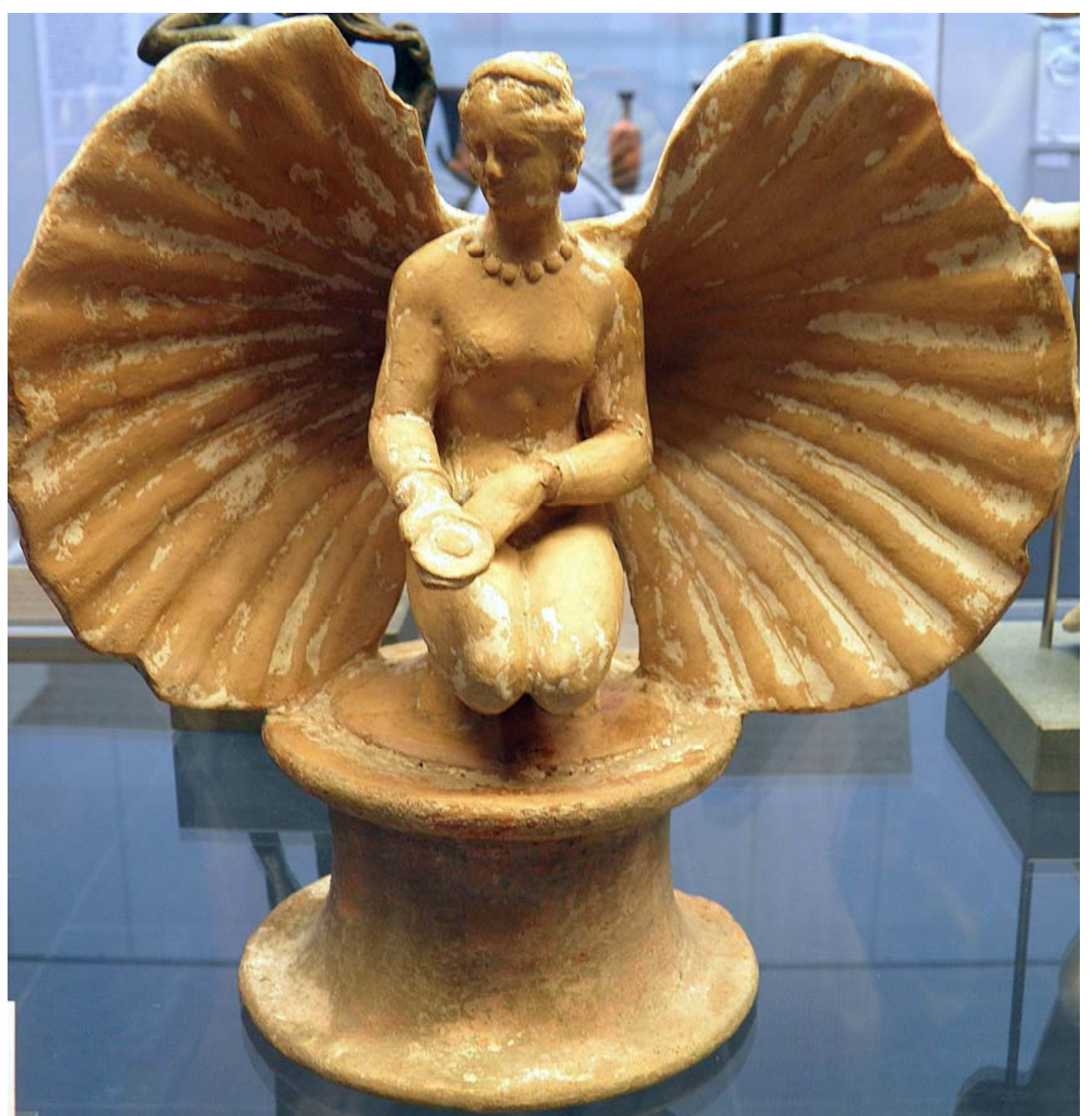

Figure 7. Aphrodite in a Shell, 3rd century BCE, Terracotta. (Staatliche Antikensammlungen, Munich, Germany; Photo credit: author. Courtesy of the Staatliche Antikensammlungen, Munich, Germany)

Furthermore, the mythological tradition comments on the divine birth, journey and name of Aphrodite born from the divine foam of the sea and transported in a seashell to the island of Cythera, known as the island of love; hence one of Venus' associations with love. ${ }^{35}$ In Roman times the seashell, or the marine gastropod mollusk, was known as venustas, hence the Greek Aphrodite became known as Venus for the Romans. The Latin noun venus meant pleasure, love, or desire, and venustas referred to charm, loveliness, or beauty. The persona of Venus became identified with love and thus with the Goddess of Love and the Goddess of Beauty. ${ }^{36}$

With these ornamentations, appropriation of classical forms, and ancient literary connotations, Tintoretto's nude muse can be identified as Venus, who is a personification of Beauty and Love. Venus, as the goddess of Beauty and Love, is an allusion to the duality of love: profane or earthly and sacred or divine, Venus is the

\footnotetext{
35 See Hesiod, Theogony, lines 31-64. Venus' cithara is decorated at the bottom with what seems to be the head of a rabbit or a dove; these are both love attributes of Venus. See also, de Tervarent, Attributs et Symboles dans L'Art Profane, pp. $133,461$.

${ }^{36}$ See Chevalier and Gheerbrant, A Dictionary of Symbols, p. 1065.
} 
clavis interpretandi for understanding the iconography of Tintoretto's Female Concert.

In the Female Concert, Tintoretto visualized a recital of music where the conductor or major protagonist is Venus among her muses. I define "muse" to mean a female who is absorbed in thoughts or in the process of a creative action. These muses are not the Ovidian muses from Ovid's Metamorphoses Book V, since these muses are five and not nine in number, and they do not reside in Helicon or in Parnassus with Apollo or Minerva. ${ }^{37}$ They do not represent the Liberal Arts but are engaged in thinking about music, interpreting musical scores and sounds, and playing music. Tintoretto replaced the Goddess Minerva (Hans Rottenhammeer's Minerva and the Muses of 1603, now in the Germanisches Nationalmuseum at Nüremberg) (see Figure 8) and the God Apollo (Jacopo Tintoretto's Apollo and the Muses or Apollo's Marriage of 1570, purchased by Egyptologist William John Bankes in Italy in 1849, and in the National Trust, London, UK since 1981), with the Goddess Venus. ${ }^{38}$

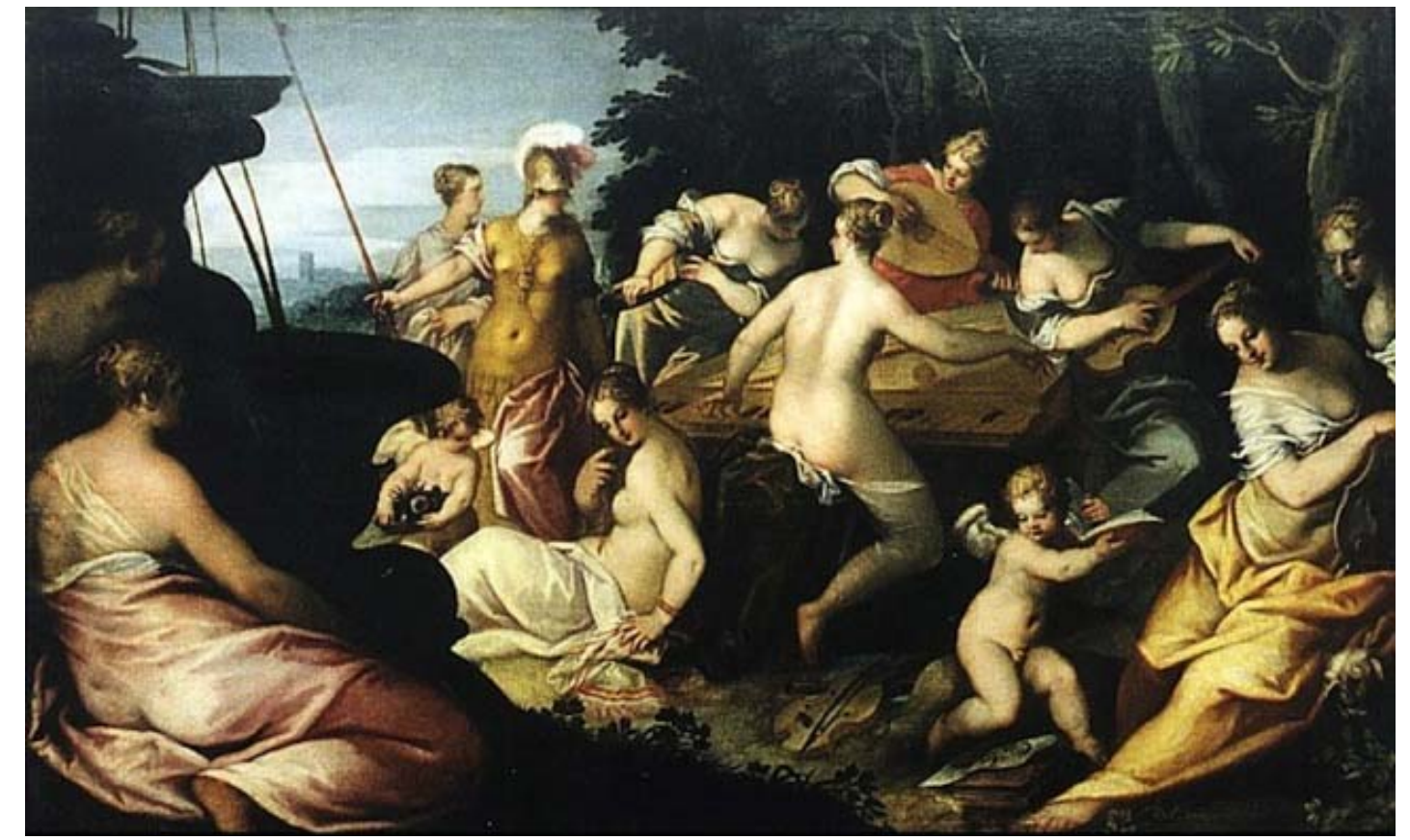

Figure 8. Hans Rottenhammer, Minerva and the Muses, 1603. (Germanisches Nationalmuseum, Nümberg, Germany; Photo credit: Public domain, via Wikimedia Commons)

In this pastoral landscape, Venus and her musical muses compose music for lovers. Variants on the theme of the Female Concert are Tintoretto's Contest among the Muses of 1544-45 (in the Bernasconi Collection at

\footnotetext{
${ }^{37}$ See Ovid The Love Poems, A. D. Melville (Ed.) (1990), p. 244, citing Ovid, Fasti, vi. 649-710, “Minerva invented the aulos but threw it away on seeing her face reflected while playing it”. See also Carla Zecher (2007), Sounding Objects: Musical Instruments, Poetry, and the Art in Renaissance France, Chapter 2, Musical Rivalries, n. 8, for a recount of the legend about Minerva inventing the aulos to perform at the feasts of the gods. At one of these celebrations, Juno and Venus began to laugh at Minerva because whenever she played the aulos her cheeks puffed distorting her beautiful face. Subsequently, Minerva discarded the instrument for providing a mundane expression; hence the wind instrument became associated with mortals.

${ }_{38}$ A recent restoration of the London painting unveils that the subject might be different alluding perhaps to a marriage scene of Apollo or Hymen, the Greek God of Marriage, see from http://www.theguardian.com/artanddesign/2010/jun/09/tintoretto-painting-restored-kingston-lacy. Furthermore, a seductive representation of Tintoretto's Apollo and the Muses of 1570s is at the Indianapolis Museum of Art, where all the figures are nude but nine in number. The provenance of this painting is still under investigation. See Cheney, “Giorgio Vasari's Pictorial Musing on the Muses”, pp. 135-177, for a study of the same theme but in a Florentine and a Roman milieu.
} 
the Castelvecchio Museum in Verona) (see Figure 10), where in Helicon nine clothed muses compete with birds for the sound of their music; Tintoretto's The Muses of 1578 (at The Royal Collection at Hampton Court in London) (see Figure 11); and Tintoretto's Apollo and the Muse of 1579 (at the Indianapolis Museum of Art) (see Figure 9), in which nine nude muses float in a celestial atmosphere while performing a concert with their musical instruments. In the background of the scenes, the aurora borealis illuminates their heavenly surroundings.

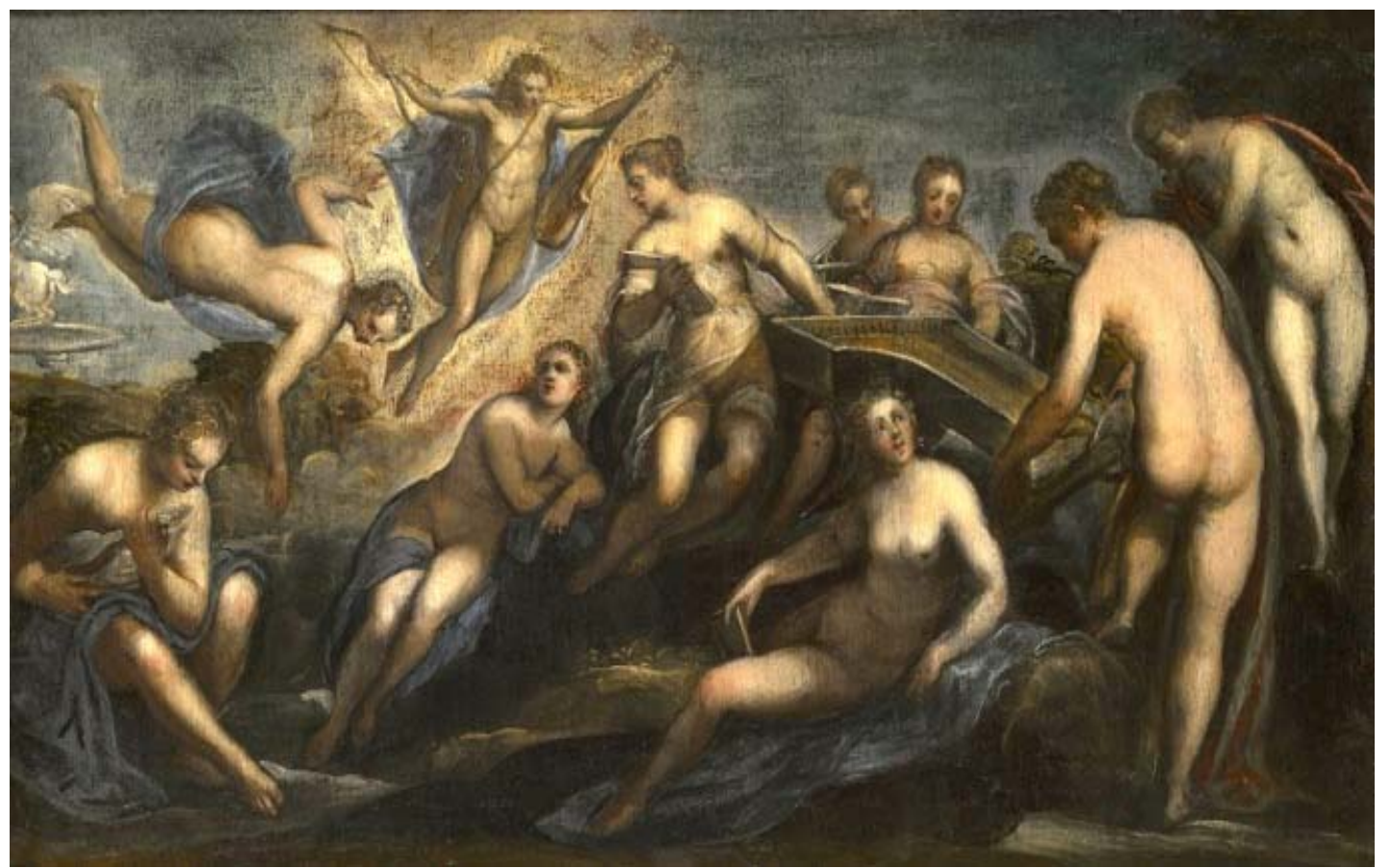

Figure 9. Jacopo or Domenico Tintoretto, Apollo and the Muses, 1570s. (Indianapolis Museum of Art, Indiana; Photo credit: The Clowes Collection, Indianapolis Museum of Art [\#2014.82])

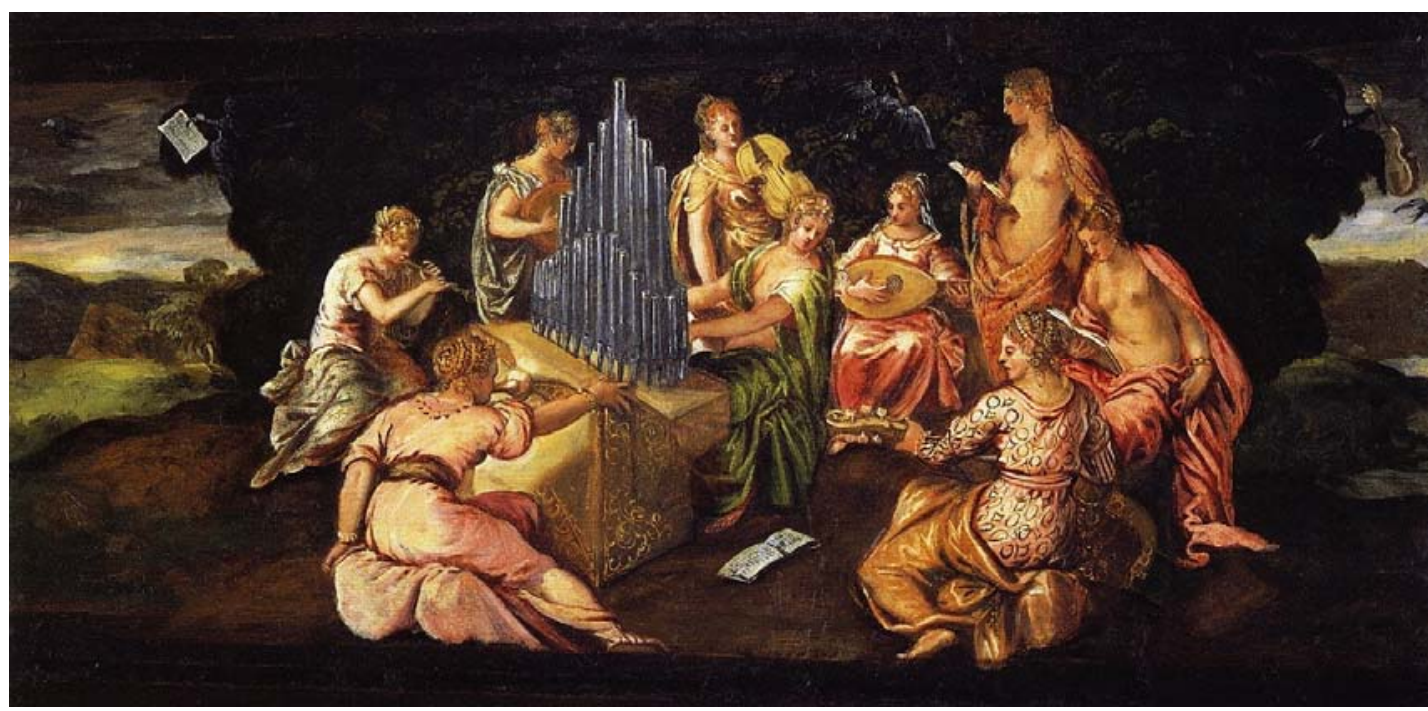

Figure 10. Jacopo Tintoretto, Contest among the Muses, 1544-45. (Bernasconi Collection, Castelvecchio, Verona, Photo credit: Scala/Art Resource, NY [ART 27731]) 


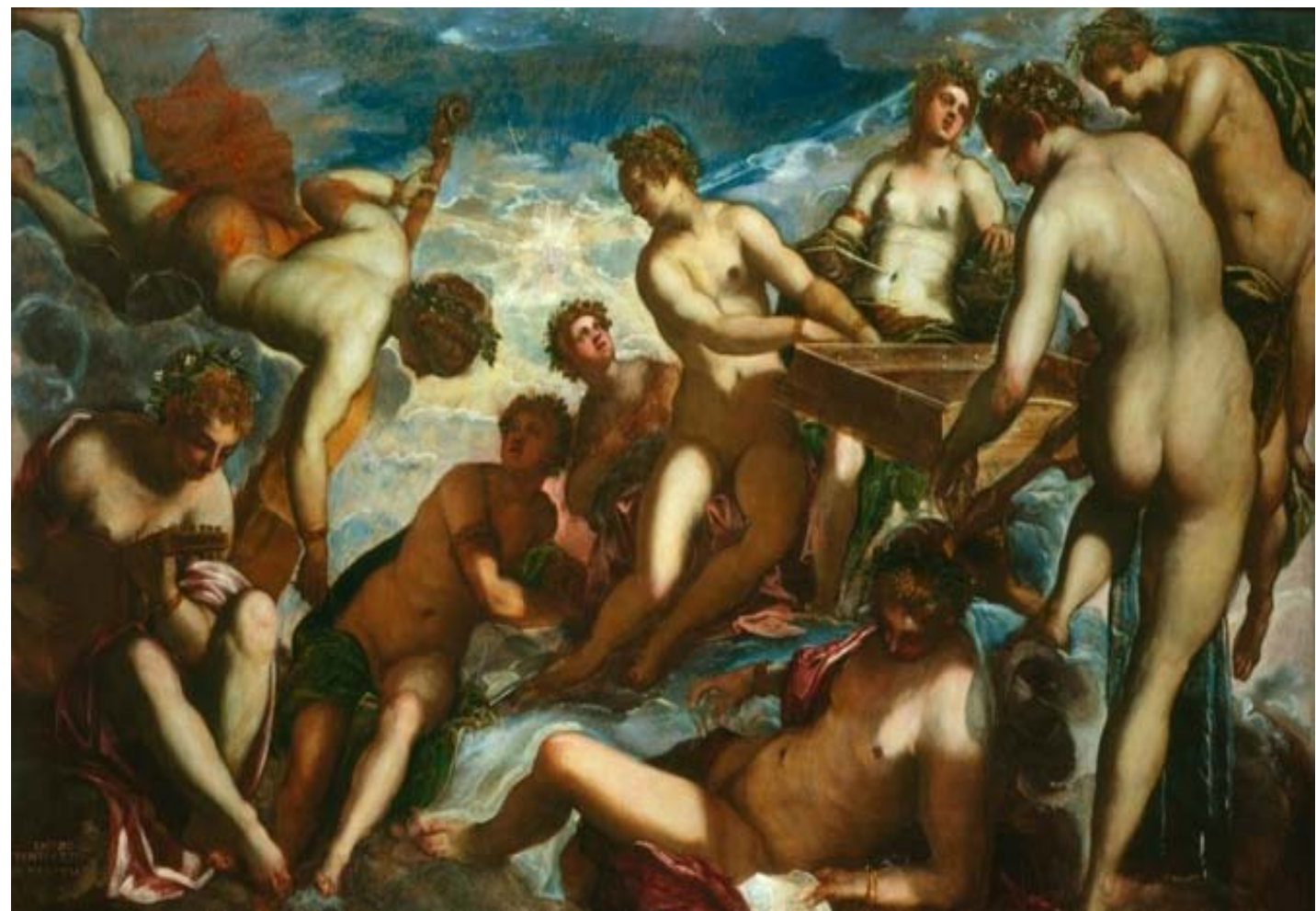

Figure 11. Jacopo Tintoretto, The Muses, 1578. (The Royal Collection, Windsor Castle, London, UK; Photo credit: Public domain, via Wikimedia Commons)

In addition, their natural forms emphasize not only their own beauty as female figures but also the beauty of composing music. Tintoretto reveals his ability to depict a beautiful nude form, an image of loveliness (venustas). ${ }^{39}$ Employing a Mannerist or Vasari's vocabulary, Tintoretto created una bella figura or belle figure. $^{40}$ Tintoretto, then, invented a realm of beauty, that is to say Venus' realm of beauty where muses play love songs. These delightful muses with their sonorous instruments also evoke amorous associations for listeners. As William Shakespeare notes in the opening words of Twelfth Night, "If music is the food of love, play on”!

\section{Paragoni (Comparisons): Art, Love, Music, Poetry, and Nature}

The paragone, an artistic comparison, is a Renaissance debate which was first established in the artistic Florentine Academy in 1547 by Benedetto Varchi (1503-65) and well articulated in the Venetian academy by Ludovico Dolce (1508-68) and by the Venetian musicians and musical theorists mentioned earlier. Inspired by

\footnotetext{
39 See Grafton, Leon Battista Alberti: Master Builder of the Italian Renaissance, 274-275, for a discussion of Vitruvius' venustas applied to the Renaissance art; Anthony Blunt (1968), Artistic theory in Italy, 1450-1600, pp. 15-18; and André Chastel (1975), Marsile Ficin et L'Art, pp. 107-114, on Alberti's concept of beauty as related to music and to Renaissance Neoplatonism.

40 See Liana De Girolami Cheney (1997), “Giorgio Vasari’s Theory of Feminine Beauty,” in Concepts of Beauty in Renaissance Art, pp. 180-190; Blunt, Artistic theory in Italy, 1450-1600, pp. 93-94; and Paola Barocchi (Ed.) (1971-1973), Scritti del Cinquecento: L'imitazione, bellezza e grazia, proporzione, misure e giudizio, 2 Vols, I, pp. 1611-1627 for Mario Equicola and Leone Ereo; II:1671-81, for Benedetto Varchi.
} 
Horace's Arts poetica and his motto ut pictura poesis or "as is poetry so is painting", ${ }^{41}$ one could apply this motto to the sister arts by saying ut pictura musica or "as is music so is painting". ${ }^{42}$ In ancient Greek culture, "poetry and music were inseparable sisters" and through the faculty of imagination they were associated with the visual arts. ${ }^{43}$ Thus as painting employs the visual elements of color, line, shape, space, and values to form a visual composition, so does music, which utilizes notes, scales, scores, sounds, and tones to create a musical composition. I propose an elaboration on Horace's motto, including the art of music in the paragone of the sister arts, thus "as is music so is painting” or "as is painting so is music".

Thus, the associations between love and music, love and poetry, and poetry and music have been long standing topics in the history of art from ancient times until today. In music, for example, there is the already established paragone between secular music and profane music, as in Lorenzo Monaco's King David of 1410 (now at the Metropolitan Museum of Art, New York), where a cithara is played by David, and Robert Testard's Allegory of Music of 1498 (Les échecs amoreaux, a manuscript in the Bibliothèque Nationale in Paris), where a cithara is played by a noble lady. Or there is the paragone between string instruments and wind instruments, as depicted in Tintoretto's Contest Between Apollo and Marsyas of 1545 (painted for a ceiling in Pietro Aretino's Palazzo Bollani, Grand Canal, Venice, now at the Wadsworth Athenaeum Museum, Hartford, CT). Another conventional paragone in art is the association with poetry or music, for example, painting versus poetry as in Raphael's Parnassus of 1511 in the Stanza della Segnatura at the Vatican; or painting versus music as in Tintoretto's Female Concert.

Tintoretto moved beyond the traditional type of artistic paragoni. In the Female Concert he presented an inventive paragone between music and nature. Beginning with the natural setting in the painting, one sees a paragone of natures that is a pastoral landscape, a natural form, versus the nude female body, a human form. Both are part of the natural world but one is physically formed by Nature while the other artificially composed by the artist. In addition, the natural body is revealed and concealed, creating a contrasting effect: in the painting there are contrasts in color between the reds and greens, while in music there is contrast between string and wind instruments or between vocal and instrumental music.

\footnotetext{
${ }^{41}$ The phrase originates from Horace's Arts poetica (line 361), 1st century BCE, who borrows the phrase from Plutarch's poem in De gloria Atheniensium, 3.347a, "Poema pictura loquens, pictura poema silens" ("Poetry is a speaking painting, painting is a silent [mute] poetry”). For further study, see Horace on Poetry: The Ars Poetica, C. O. Brink (Ed.) (1971). In the Italian Renaissance, Cristoforo Landino (1424-98) popularized Horace's phrase in his edition of Horatius cum quattuor commentariis (1498), citing Horace's passage: ut pictura poesis erit; non erit dissimilis/poetica ars picturae; Jean H. Hagstrum (1958), The Sister Arts: The tradition of Literary Pictorialism and English Poetry from Dryden to Gray, p. 59; L. Mendelsohn (1982), Paragoni: Benedetto Varchi Due Lezzioni and Cinquecento Art Theory, pp. 109-142, where Varchi notes in the third disputation, "Onde, se bene i poeti et i pittori imitano, non imitano però, ne le medesime cose, nei medesimi modi. Imitano quelli colle parole, e questi co' colori; il perché pare che sia tanta differenza fra la poesia e la pittura, quanta è fra l'anima e'l corpo. Bene è vero che, come i poeti descrivono ancora il di fuori, così i pittori mostrano quanto più possono il di dentro, cioè gli affetti." See also John R. Spencer (1957), "Ut Rhetorica Pictura: A Study in Quattrocento Theory of Painting”, Journal of the Warburg and Courtauld Institutes, 20, 26-44; Blunt, Artistic Theory in Italy, p. 52; Rensselaer Lee (1967), Ut Pictura Poesis: Humanist Theory of Painting, 1, n. 2; Dolce's Dialogo della Pittura (1557), M. Roskill (Trans.) (1968), pp. 97, 239; and Gian Paolo Lomazzo (1584), Trattato dell' arte della pittura, scultura et architettura, which summarizes Leonardo's and Dolce's conceptions of the relationships between poetry and painting. See K. Borinski (1914-1924), Die Antike in Poetik und Kunsttheorie von Ausgang des klassischen Altertums bis auf Goethe und Wilhelm von Humboldt, 2 Vols., I, pp. 30, 97, 175, 183, 238; II, p. 106, and, in particular, pp. 125-127, on the history of the dispute about ut pictura poesis; and Mario Praz (1967), Mnemosyne: The Parallel Between Literature and the Visual Arts, pp. 2-28.

42 See Hagstrum, The Sister Arts, p. 9.

43 See Werner Jaeger (1943), Paideia: The Ideals of Greek Culture, Gilbert Highet (Trans.), 3 Vols., II, p. 224.
} 
Another paragone is associated with music and the senses, that is, the sensory (hearing) playing of music versus seeing or reading musical scores. Tintoretto emphasized this paragone by depicting female nudes holding or playing musical instruments, while some of the clothed females are reading or pointing to the musical notes. In this type of paragone, viewers act as participants as well as perceivers of the painting.

One more sensory paragone is musical: the sense of touch depicted between the musical instruments being performed or ready to be played—such as the viola da gamba, cittern and regal—contrasting with those resting or not played, such as the lira da braccio and the psaltery. In this type of paragone, Slim suggests an allusion between the religious psaltery of biblical times played by King David and the secular lira da braccio of the Renaissance played by Apollo. Perhaps the paragone is yet more complex, relating to the sound of the instruments when played, with the lira da braccio, for example, having a stronger affinity with sound of the viola da gamba (both being string instruments played with a bow) and with both the psaltery and the cithara having metal strings that are plucked with a plectrum. Or perhaps because the muse who is holding the viola da gamba touches the bow of the lira da braccio this suggests her ability to play both instruments. The psaltery resting next to the regal may suggest that those muses have the ability to play both instruments as well. In this case the paragone maybe associated with artistic presentation, a different type of performance accompanied with natural talent and acquired skills.

There are several associations with music, love and Venus in the painting. For example, the clothed muse points Venus to a musical passage for her to play from the Neapolitan song Dolc'amorose e leggiadrette ninfe. ${ }^{44}$ The second legible score includes the first lines of the madrigal: "Quanto lieta ver noi sorge l'Aurora at the feet of Venus." 45 The lines of the song allude to the sunrise light seen in the painting as well to the spring setting, Venus' season. In addition, they allude to Venus embracing a cithara, most likely relating to a recently published book, as explained above.

The association of music with the realm of Venus and her season, spring, is also noted in astrological, alchemical and philosophical books during the Quattrocento and Cinquecento, such as Gabriele Giolito Ferrari’s Venus and Her Children, from Planetary Gods, published in Venice 1533; Solomon Trimosin's Venus and Her Children of 1532, from Splendor solis at the Gemäldegalerie in Berlin; and Marsilio Ficino's De vita coelitus comparanda ("How Life Should Be Arranged According to the Heavens"). ${ }^{46}$ Astrologically, those individual born under Venus' sphere are referred to as the children of Venus. ${ }^{47}$ They partake of Venus' celestial and earthly realms. With harmonious bliss, they reside in a celestial realm of beauty and love; whereas in the earthy realm, they experience an élan de vivre in a cultivated garden, pursuing pleasure through love

\footnotetext{
${ }^{44}$ See Slim, “Tintoretto’s Music-Making”, p. 51. Slim notes that the Neapolitan song was published in Giovan Leonardo Primavera's Il primo libro de canzone napoletane a tre voci in Venice by Girolamo Scotto in the 1565, 1566 and 1570 editions.

${ }^{45}$ See Slim, “Tintoretto's Music-Making”, p. 53. He also identified the score in the open sheet of music at the foot of Venus as being from a madrigal of Andrea Gabrieli published in a musical book Il primo libro di madrigal a cinque voci in Venice by Antonio Gardano in 1566 and 1572.

${ }^{46}$ See Paolo Galluzzi (Ed.) (2009), Galileo: Images of the Universe from Antiquity to the Telescope, p. 302 on Gaffurrius' Practica musicae; pp. 185-188, on Venus and the Children of Venus; and p. 304, on Baccio Baldini's depiction of the Seven Planets of 1460, including Venus. See also, Peter J. Forshaw, "Marsilio Ficino and the Alchemical Art", in Laus Platonici Philosophi: Marsilio Ficino and His Influence, Stephen Clucas, Peter J. Forsaw and Varely Rees (Eds.) (2008), pp. 251-71; Thomas Moore, The Planets Within: The Astrological Psychology of Marsilio Ficino (Hudson, NY: Lindisfarne Press, 1990), pp. 137-147; Marsilio Ficino (Ed.), The Book of Life, Carol V. Kaske and John R. Clark (1998), pp. 20-22 and pp. 33-36; and Marsilio Ficino, The Book of Life, Charles Boer (Trans.) (1980), pp. 64-67.

${ }^{47}$ See also Gwendolyn Trottein, Les enfants de Venus: Art et Astrologie a la Renaissance (1993), pp. 90-113, 173-76; and Paolo Galluzzi (Ed.), Galileo: Images of the Universe from Antiquity to the Telescope (2009), pp. 185-188, on Venus and the Children of Venus.
} 
making, music making and dancing as illustrated in Baccio Baldini's Venus and Her Children of 1464, an engraving from The Seven Planets, in the Print Collection of the British Museum in London; Cristoforo de Predis' Astrological Planets: Venus and Her Children in De Sphaera of 1466-75, an illuminated manuscript in the Biblioteca Estense in Modena; and Gabriele Giolito de' Ferrari’s Venus and Her Children, an engraving from Planetary Gods, published in Venice 1533.

Earlier in Venice, Franchinus Gaffurius (1451-22), a northern Italian music theorist and composer, emphasized the astral connection with music as seen in the woodcut chart in Practica musicae of 1496, published in Venice in $1505{ }^{48}$ Music is not only a practical art for Gaffurius but also a philosophical discipline connected with the movement of the celestial bodies, a Neoplatonic conceit. For Marsilio Ficino (1433-99), the Renaissance Neoplatonic philosopher, music connected with the realm of Venus and the human person with the divine, "the soul receives the sweetest harmonies and numbers through the ears, and by these echoes is reminded and aroused to the divine music that may be heard by the more subtle and penetrating sense of mind". ${ }^{49}$ In De amore (Sopra Lo Amore or On Love), Ficino introduced the duality in the universe: nature versus celestial, physical versus metaphysical, and human versus divine. ${ }^{50}$ This dualism is appropriate in the realm of Venus, hence creating two types of Venus, earthly or human and celestial or divine. The heavenly or celestial Venus is born from the heavens through the castration of Uranus, while the earthly Venus is formed from the union of Jupiter and Juno. The celestial Venus resides in the Neoplatonic Cosmic Mind or Intellect. In this heavenly realm she imparts spiritual beauty and divine love or sacred love (amor divinus). The Earthly Venus, in contrast, partakes of the World-Soul or the human world where she imparts natural beauty and human love or profane love (amor humanus). ${ }^{51}$ Ficino's two Venuses create as well a paragone (comparison) between the divine and natural realms. ${ }^{52}$

The Milanese physician, mathematician, and music theorist Gerolamo Cardano (1501-76) applied Ficino’s dualities to music in noting, "Music celebrates moral virtues...since emotions and music consists of gentle virtues...corresponding to [human] actions, and of divine virtues relating to the intellect” ${ }^{53}$ In Istitutioni Harmoniche (Venice 1573), Zarlino, under Ficinian influence, postulated like Cardano the formation of two types of realms, musica mundana, which unites the principles of harmony in the macrocosm or the celestial sphere, and musica humana, which connects harmony to the microcosm or the human sphere, thus creating a

\footnotetext{
48 See Practica Musicae by Franchinus Gaffurius, Clement A. Miller (Ed.) (1968), and Irwin Young (Trans. \& Ed.) (1969), The Practica musicae of Franchinus Garffurius.

${ }^{49}$ See D. P. Walker (2000), Spiritual and Demonic Magic: From Ficino to Campanella, pp. 3-29, for a discussion on Ficino and Music; also see The Letters of Marsilio Ficino, Members of the Language Department of the School of Economic Science (Trans. \& Ed.) (1975), 5 Vols., I, p. 45.

50 See Marsilio Ficino (2003), De Amore: Sopra lo amore ovvero Convito di Platone, ed. Giuseppe Rensi, p. 101: "Siano dunque due Veneri nella anima la prima celeste, la seconda vulgare: ambe due abbino lo Amore: la celeste abbia lo amore a cogitare la divina Bellezza: la vulgare abbia lo Amore a generare la bellezza medesima nella materia del Mondo" ("There are two Venus in the soul the first is celestial, the second is earthly: both contain Love: the celestial [Venus] embraces Love in cogitating on divine Beauty: the earthly [Venus] expresses love in creating Beauty in the natural forms in the World"). See also Chastel, Marsile Ficin et L'Art, pp. 121-128, for a discussion of the two Ficinian Venuses and sacred and profane love.

${ }^{51}$ See also Moore, The Planets Within, p. 140.

52 See Mendelsohn, Paragoni: Benedetto Varchi Due Lezzioni and Cinquecento Art Theory, pp. 109-142, and Heinrich F. Plett (2004), Rhetoric and Renaissance Culture, pp. 297-364, for a discussion on the origin of the concept of the paragone in Italian Renaissance art, commencing with the writings of Leonardo da Vinci's Treatise on Painting, where he emphasizes the superiority of painting over sculpture. See also, Paragone: A conception of the Arts by Leonardo da Vinci, Irma A. Richter (Trans. \& Ed.,) (1949), Introduction.

53 See Hieronymus Cardanus, Writings on Music, Clement A. Miller (Trans. \& Ed.,) (1937), pp. 105, 213, and Comensoli, “Music, The Book of the Courtier", pp. 100, 102, no. 12.
} 
cosmos where the natura spirituale (soul) and the natura coporeale (body) form a concordia harmonica (harmony of the spheres). ${ }^{54}$ This musical utopia was also revealed in the mythographic iconography of Vincenzo Cartari's celestial cosmos, the Imagini delli Dei degli'Antichi, published in Venice in 1557.

In the Prague court, Rudolph II (1552-12), the patron of Tintoretto, encouraged the study of occult sciences and hosted the renowned astronomers Tycho Brahe (1546-1601) and Tommaso Rangone, ${ }^{55}$ and alchemists John Dee (1527-1608) and Edward Kelley (1555-97). Tintoretto, in the Female Concert, revealed a realm of Venus, connecting music with the sphere of Venus, creating a harmonia mundi (harmony of the spheres) with beauty and love, visualizing the planetary interests of the Rudolph II, which are also shown in his cabinet of curiosities (kunstkammer). ${ }^{56}$

\section{Conclusion}

In the Female Concert, Tintoretto represented an aspect of Zarlino's harmony of the spheres, a celestial (natura spirituale) and terrestrial (natural corporeale) realm of Venus, where her planetary influence leads Aurora's morning brilliant $\operatorname{star}^{57}$ and her physical beauty guides the female muses to arouse love with the sound of their music. There are also two contrasting Venuses in Tintoretto's painting. On the left of the painting, the muse wrapped in a red cloak and holding the viola da gamba is the only female wearing pearl earrings and whose pudendum is covered with a transparent veil (see Figure 12), covering her nature for modesty as she turns toward the viewer. ${ }^{58}$ She is the only muse who does not need a musical score to play her instrument, her inspiration is divine; hence she may allude to the Neoplatonic Celestial Venus or natura spirituale. Opposite to her, a voluptuous female, her back facing to the viewer, adorned with golden bracelets and gemstones and guided in her musical performance, may personify Earthly Venus or natura corporeale. In the dominion of Venus, the muses compose music to endow the "children of Venus" and those born under her sign with physical beauty and spiritual love. In Venus' sphere, the celestial and earthly realms are created by the symphony of sounds and experienced by the pleasure of the senses are in perfect harmony (concordia harmonica); "this metaphor of love is the noblest in keeping with Neoplatonic ideals". 59

\footnotetext{
54 See Walker, Spiritual and Demonic Magic: From Ficino to Campanella, p. 28.

55 See Tom Nichols (1999), Tintoretto: Tradition and Identity, pp. 135-138, regarding Tintoretto’s patrons, in particular, Rudolph II, and Tommaso Rangone, a physician and astrologer in the court of the Holy Roman Empire, pp. 136-147. On Pietro Aretino owning Tintoretto’s painting Contest of Apollo and Marsyas in his Palazzo Bollani on the Gran Canal in Venice, p. 138.

${ }^{56}$ See Thomas DaCosta Kaufmann (Autumn 1978), "Remarks on the Collections of Rudolf II: The Kunstkammer as a Form of Representation”, Art Journal, 38(1), 22-28; R. J. W. Evans (1984), Rudolf II and his world: A study in intellectual history, 1576-1612, (2nd ed.); and Peter Marshal (2006), The Magic Circle of Rudolf II: Alchemy and Astrology in Renaissance Prague.

${ }^{57}$ Aurora is considered the morning start and Lucifer (Light Ringer) is an appellation for Venus; see from http://www.thaliatook.com/OGOD/aurora.html.

58 See Biedermann, Dictionary of Symbolism, p. 365.

59 See Alberto Ausoni (2005), Music in Art, p. 30.
} 


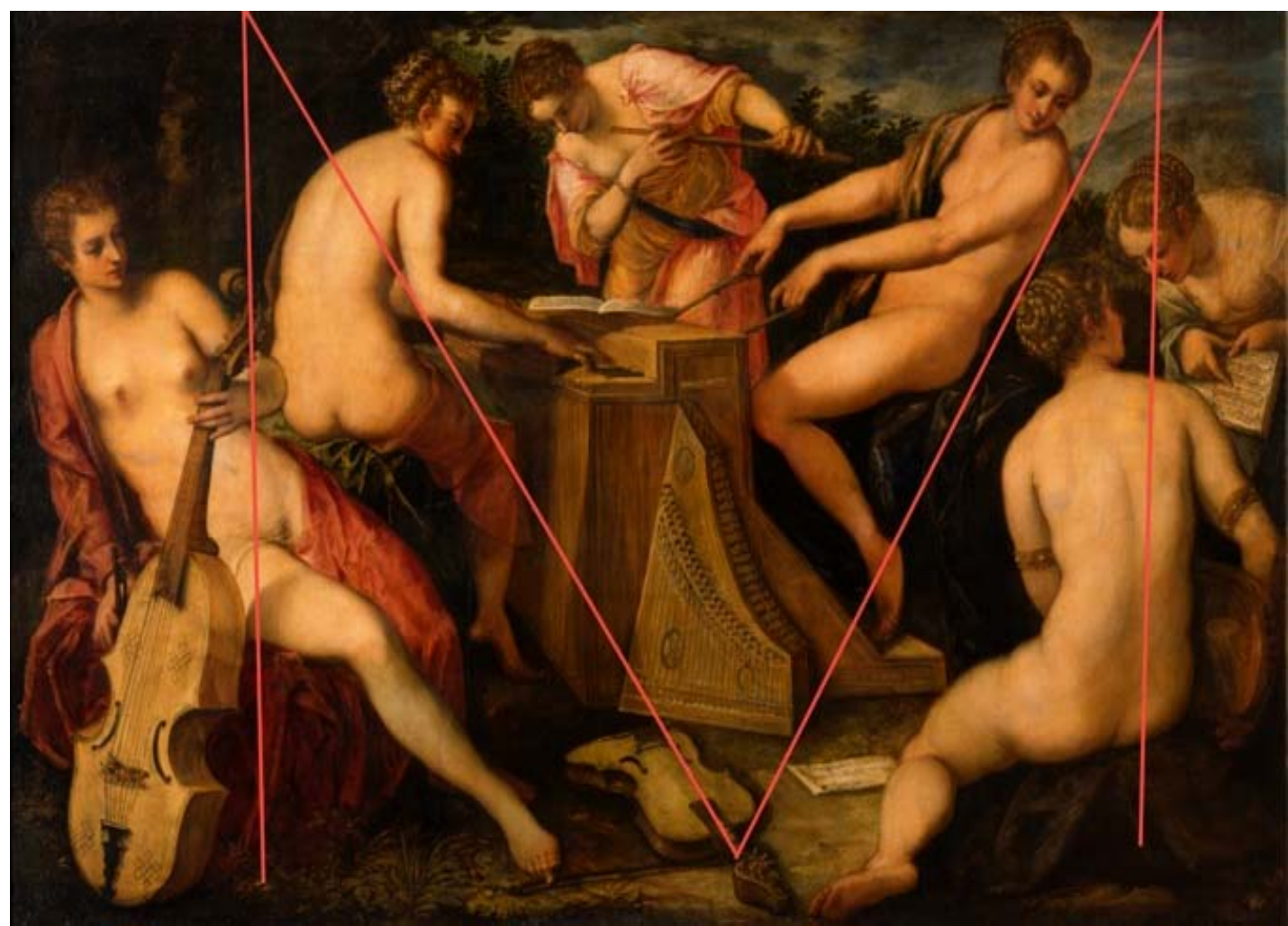

Figure 12. Cheney's suggested composition of the initials M(usic) and V(enice) or M(arietta) in Tintoretto, Female Concert.

Reflecting on the axial design of diagonals and vertical lines in composition, and the relationship between the muses and the musical instruments, leads to several further observations. The initial letters " $\mathrm{M}$ " and "V" are formed in the composition of the painting; " $\mathrm{M}$ " probably alluding to the muses and their musical compositions $^{60}$ and "V" referring to Venus and venustas, beauty.

The placement of the lira da braccio on the ground and between the muses-one is facing the viewer while displaying the viola da gamba, and the other muse is Venus, who presents her back to viewer while holding the cithara-emphasizes a paragone, a sovereignty of string instruments over wind instruments. There is also an allusion to the contrast between profane and divine music. The partially clothed muse resting on the viola da gamba, while touching with one of her toes the bow resting next the lira da braccio, performs profane music, while the goddess Venus, who holds a cithara, plays divine music.

In addition, the placement of the lira da braccio suggests an association between the lifeless and living realms of music and nature. Although the lira da braccio with its curved shape is a lifeless object, it resembles in its form the natural body of the muses. Its sound will not be perceived until it is played by one of the muses. In contrast, the muses, with their beautiful bodies, will not only elicit visual arousal but will also, with their ability to play the musical instruments, awaken the soul of the individual.

Thus, it is not by accident that the composition is designed with an "M" for music and a "V" for Venus; Tintoretto's Female Concert is a conceit of music and love, a realm of Venus, where beautiful muses compose musical love songs.

\footnotetext{
${ }^{60}$ Perhaps the initial "M" also refers to the name of his daughter Marietta, who was a musician and a painter. In observing the physiognomy of the muses, it is easy to see an idealized resemblance to Marietta's face.
} 


\section{References}

Akasofu, S. I. (1979/1994). Aurora Borealis. Alaska Geographic Society 6, 2(124), 26.

Andrews, T. (1998). A dictionary of nature myths: Legends of earth, sea and sky. Oxford: Oxford University Press.

Ausoni, A. (2005). Music in art. Los Angeles: J. Paul Getty Museum.

Baldauf-Berdes, J. L. (1996). Women musicians of Venice: Musical foundations, 1525-1855. Oxford: Clarendon Press.

Barocchi, P. (Ed.). (1971-73). Scritti del Cinquecento: L'imitazione, bellezza e grazia, proporzione, misure e giudizio (Sixteenth century writings: Imitation, beauty and grace, proportion, measure and judgment) (2 Vols.). Milan: Giulio Einaudi.

Biedermann, H. (1994). Dictionary of symbolism: Cultural icons and the meanings behind them. New York: Meridian Books.

Blunt, A. (1968). Artistic theory in Italy, 1450-1600. Oxford: Oxford University Press.

Bober, P. P., \& Rubenstein, R. (1986). Renaissance artists and antique sculpture. Oxford: Oxford University Press.

Borinski, K. (1914-24). Die Antike in Poetik und Kunsttheorie von Ausgang des klassischen Altertums bis auf Goethe und Wilhelm von Humboldt (The antique in poetry and art theories from the classics to Goethe and William von Humboldt) (2 Vols.) Leipzig: K. F. Koehler.

Brink, C. O. (Ed.). (1971). Horace on poetry: The ars poetica. Cambridge: Cambridge University Press.

Cardanus, H. (1937). Writings on music. C. A. Miller, (Trans. \& Ed.). Dallas, TX: American Institute of Musicology.

Chastel, A. (1975). Marsile Ficin et L'Art. Geneva: Droz.

Cheney, L. De G. (1977). Giorgio Vasari’s theory of feminine beauty. In Concepts of beauty in renaissance art (pp. 180-194). London: Scolar/Ashgate Press.

Cheney, L. De G. (1994). Giorgio Vasari's pictorial musing on the muses: The chamber of Apollo of the Casa Vasari. Studies in Iconography, 15, 135-77.

Cheney, L. De G., Russo, K., \& Faxon, A. (2000/2011). Self-portraits by women painters. London: Ashgate and Washington, DC: New Academia Publishers.

Chevalier, J., \& Alain, G. (1994). A dictionary of symbols. Oxford: Blackwell.

Comensoli, V. (1998). Music, The Book of the Courtier, and Othello's soldiership. In M. Marrapodi (Ed.), The Italian world of English Renaissance drama: Cultural exchange and intertextuality (pp. 89-105) Cranbury, NJ: Associated University Presses.

DaCosta Kaufmann, T. (1978). Remarks on the collections of Rudolf II: The Kunstkammer as a form of representation. Art Journal, 38(1), 22-24.

Dolce’s Dialogo della Pittura (1557).Venice: G. Giolito de’ Ferrari.

Dudik, B. (1867). Die Rudolfinische Kunst-und Rarirätenkammer in Prag (Rudoph's art and chamber of rarities in Prague). Mitteilungen der K. K. Central Commission zur Erforschung und Erhaltung der Baudenkmale, 12, XXXIX, no. 291.

Evans, R. J. W. (1984). Rudolf II and his world: A study in intellectual history, 1576-1612. Oxford: Clarendon Press.

Fenlon, I. (1994). Music, print and culture in early sixteenth-century Italy (The Panizzi Lectures). London: British Museum.

Ficino, M. (1980). The book of life. (C. Boer, Trans.). Dallas, TX: Spring Publications.

Ficino, M. (1998). The book of life. C. V. Kaske and J. R. Clark, (Eds.). Tempe, AZ: Medieval and Renaissance Texts and Studies.

Ficino, M. (2003). De Amore: Sopra lo amore ovvero Convito di Platone (On Love: On Love discussed in Plato's symposium). G. Rensi, (Ed.). Milan: SE SRL.

Forshaw, P. J. (2008). Marsilio Ficino and the alchemical art. In S. Clucas, P. J. Forsaw, and V. Rees (Ed.), Laus Platonici Philosophi: Marsilio Ficino and His Influence (pp. 251-271). Leiden: Brill.

Galluzzi, P. (Ed.). (2009). Galileo: Images of the universe from antiquity to the telescope. Florence: Giunti.

Grafton, A. (2000). Leon Battista Alberti: Master builder of the Italian Renaissance. Cambridge, MA: Harvard University Press.

Hagstrum, J. H. (1958). The sister arts: The tradition of literary pictorialism and English poetry from Dryden to Gray. Chicago: Chicago University Press.

Hesiod. (1832). Theogony. C. A. Elton, Esq., (Trans. and annotated). London: A. J. Valpy.

Hesiod. (1988). Theogony. M. L. West, (Trans. \& Ed.). Oxford: Oxford University.

Hübner, J. (1856/1862/1868). Verzeichnis der Königlichen Gemälde-Gallerie zu Dresden (Directory of the Royal Gallery Collection in Dresden). Dresden: Forschngsstelle Publisher.

Jaeger, W. (1943). Paideia: The ideals of Greek culture (G, Highet, Trans., 3 Vols.). Oxford: Oxford University Press.

Lee, R. (1967). Ut Pictura Poesis: Humanist theory of painting. New York: W. W. Norton and Company, Inc. 
Lomazzo, G. P. (1598). Trattato dell' arte della pittura, scultura et architettura (Treatise on the art of painting, sculpture and architecture). Milan: P. G. Pontio.

Marshal, P. (2006). The magic circle of Rudolf II: Alchemy and astrology in Renaissance Prague. London: Waker and Company.

Melville, A. D. (Ed.). (1990). Ovid the love poems. Oxford: Oxford University Press.

Mendelsohn, L. (1982). Paragoni: Benedetto Varchi Due Lezzioni and Cinquecento art theory (Comparisons: Benedetto Varchi’s Two Lessons and sixteenth-century art theory). Ann Arbor: UMI Research Press.

Miller, C. A. (Ed.). (1968). Practica Musicae by Franchinus Gaffurius (Musical transcriptions of Franchinus Gaffurius). Dallas, TX: American Institute of Musicology.

Moore, T. (1990). The planets within: The astrological psychology of Marsilio Ficino. Hudson, NY: Lindisfarne Press.

Nichols, T. (1999). Tintoretto: Tradition and identity. London: Reaktion Books.

Pallucchini, R., \& Rossi, P. (1982). Jacopo Tintoretto: Le opere sacre e profane (Jacopo Tintoretto: Sacred and profane works). Milan: Electa.

Pendle, K. (Ed.). (1991). Women and music: A history. Indianapolis: Indiana University Press.

Plett, H. F. (2004). Rhetoric and renaissance culture. New York: Walter de Gruyter.

Praz, M. (1967). Mnemosyne: The parallel between literature and the visual arts. Princeton: Princeton University Press.

Richte, I. A. (Ed. \& Trans.). (1949). Paragone: A conception of the arts by Leonardo da Vinci. Oxford: Oxford University Press.

Ridolfi, C. (1984). Life of Tintoretto, and his children Domenico and Marietta. (R. Enggass, Trans., 2 Vols.). University Park: Pennsylvania State University Press.

Ridolfi, C. (2006). Le Maraviglie dell'Arte (The wonders of art) (2 Vols.). Padua: Elibron.

Rosand, D. (1986/1997). Painting in cinquecento Venice: Titian, Veronese, Tintoretto. New Haven: Yale University Press.

Roskill, M. (Trans.). (1968). Dolce's Dialogo della Pittura (Dolce’s dialogue on painting). New York: New York University Press.

Rotraud, B. R. (1976). Die Kunstkammer Kaiser Rudolfs II. In Prag: Inventar aus den Jahren 1607-1611 (Emperor Rudolph II’s Cabinet of Curiosities: Prague Inventary 1607-1611). Jahrbuch der Kunsthistorischen Sammlungen in Wien 72. (N.p: n.p.), XIV (report from 5 March 1612).

Sansovino, F. (1581). Venetia città nobilissima (Venice noble city). Venice: Iacopo Sansovino.

Siscoe, G. (1986). An historical footnote on the origin of “Aurora Borealis”. History of Geophysics, 2, 11-14.

Slim, H. C. (1987). A painting about music at Dresden by Jacopo Tintoretto. Exploration in Renaissance Culture, 13, 1-18.

Slim, H. C. (1988). Tintoretto’s music-making women at Dresden. Imago Musicae, 4, 45-76.

Spencer, J. R. (1957). Ut Rhetorica Pictura: A study in quattrocento theory of painting. Journal of the Warburg and Courtauld Institutes, 20, 26-44.

Tervarent, G. de. (1977). Attributs et Symboles dans L'Art Profane (Attributes and symbols in profane art). Geneva: Droz.

Trottein, G. (1993). Les enfants de Venus: Art et Astrologie a la Renaissance (The children of Venus: Art and astrology in the Renaissance). Paris: Lagune.

Vasari, G. (1568). Vita di Jacopo Tintoretto (The life of Jacopo Tintoretto). In R. Bettarini and P. Barocchi (Eds.), Giorgio Vasari Vite de' più eccellenti Pittori, Scultori e Architettori nelle redazioni del 1550 e 1568 (Giorgio Vasari's Lives of the most excellent painters, sculptors and architects in the editions of 1550 and 1568) (6 Vols.) (pp. 1963-1998). Florence: G.C. Sansoni.

Walker, D. P. (2000). Spiritual and demonic magic: From Ficino to Campanella. University Park: The Pennsylvania State University Press.

Weddigen, E. (1984). Jacopo Tintoretto und die Musik (Jacopo Tintoretto and music). Artibus et Historiae, 5(10), 67-119.

Young, I. (Ed. \& Trans.). (1969). The Practica musicae of Franchinus Garffurius (The musical transcriptions of Franchinus Gaffurius). Madison: The University of Wisconsin Press.

Zecher, C. (2007). Sounding objects: Musical instruments, poetry, and the art in Renaissance France. Toronto: University of Toronto Press.

Zimmerman, H. (1905). Das Inventar der Prager Schartz-und Kunstkammer vom 6. Dezember 1621 (Prager Schartz’ Inventory and Chamber of Curiosities, December 6, 1621). Jahrbuch der kunsthistorischen Sammlungen des allerhöchsten Kaiserhauses. N.p: n.p.: XLII, no. 1036. 